\title{
Evolution of a mafic volcanic field in the central Great Basin, south central Nevada
}

\author{
G. M. Yogodzinski, ${ }^{1}$ T. R. Naumann, ${ }^{2}$ E. I. Smith, and T. K. Bradshaw ${ }^{3}$ \\ Center of Volcanic and Tectonic Studies, Department of Geosciences, University of Nevada, Las Vegas
}

J. D. Walker

Isotope Geochemistry Laboratory, Department of Geology, University of Kansas, Lawrence

\begin{abstract}
Evolution of a mafic volcanic field is investigated through a study of Pliocene age rocks in the Reveille Range in south central Nevada. Pliocene activity began with the eruption of relatively abundant hawaiite (episode 1, 5-6 Ma), which was followed by trachytic volcanism (4.3 Ma) and by a second episode of lower-volume hawaiite and basanite (episode 2, 3.0-4.7 Ma). Incompatible elements indicate an asthenospheric source. Isotopically, episode 2 basalts cluster around ${ }^{87} \mathrm{Sr} / 86 \mathrm{Sr}=0.7035$ and $\varepsilon_{\mathrm{Nd}}=+4.2$, but episode 1 samples vary to high ${ }^{87} \mathrm{Sr} / 86 \mathrm{Sr}$ (up to 0.7060 ) over a narrow range of $\varepsilon_{\mathrm{Nd}}(+0.8$ to +4.5 ). Trachytic rocks (MgO $0.5 \%$ ) are isotopically akin to the episode 1 basalts. Geochemical variation requires the addition of a crustal component (high ${ }^{87} \mathrm{Sr} / 86 \mathrm{Sr}, \mathrm{Sr} / \mathrm{Nd}, \mathrm{Pb} / \mathrm{La}$, low $\varepsilon_{\mathrm{Nd}}$ ) to the episode 1 hawaiites and trachytic samples, probably by assimilation of carbonate-rich sedimentary wall rock. The volcanic field developed in at least two eruptive cycles of approximately equal duration. Basanites (deeper and lower percentage melts) appear only in the younger episode. Eruptive episodes were apparently linked to separate melting events in the mantle. Through time, basalts were produced in diminishing volumes by lower percentage melting, magma generation and storage was at greater depths, and magma ascent was at higher velocities. Spatially, the melting anomalies were large in the Pliocene but progressively diminished in size so that by Pleistocene time, volcanism was restricted to a small area near the northern end of the initial outbreak.
\end{abstract}

\section{Introduction}

The study of Miocene and Pliocene age mafic volcanic rocks associated with Cenozoic crustal extension in the western United States continues to provide insight into a variety of geologically important processes and systems. These include lithospheric-scale tectonic features of rifting on continental crust, important aspects of the crust-mantle geochemical system, and clues to the nature of magmatic differentiation and the genesis of igneous rocks in the continental rift environment [e.g., Leeman, 1982; Menzies et al., 1983; Fitton et al., 1988; Glazner et al., 1991; Glazner and Farmer, 1992; Bradshaw et al., 1993].

Previous and ongoing studies have shown that there is a twofold geochemical division among Pliocene and younger mafic volcanic rocks in the Basin and Range region [Menzies et al., 1983; Fitton et al., 1988; Ormerod et al., 1988; Rogers et al., 1995]. This twofold division is most often interpreted to reflect compositionally distinct sources in the asthenospheric and lithospheric mantle [see also Leeman, 1970; Hedge and Noble, 1971; Leeman, 1982; Fitton et al.,

\footnotetext{
${ }^{1}$ Now at Department of Geology, Dickinson College, Carlisle, Pennsylvania.

${ }^{2}$ Now at Department of Geology, University of Idaho, Moscow.

${ }^{3}$ Now at House of Lords Committee Offices, London.
}

Copyright 1996 by the American Geophysical Union.

Paper number 96JB00816.

0148-0227/96/96JB-00816\$09.00
1988; Farmer et al., 1989]. The assimilation of continental crust is regarded by most workers to be of minor petrogenetic importance [e.g., Leeman, 1982; Menzies et al., 1983; Fitton et al., 1988 ], though there are cases where crustal assimilation is thought to have been a primary control over Basin and Range basalt geochemistry [e.g., Glazner et al., 1991; Glazner and Farmer, 1992].

End-members in the geochemical spectrum of Basin and Range basalts are well represented in mafic volcanic rocks that occur within the NNE trending zone of Pliocene and younger mafic volcanism that extends from Death Valley on the south, to the Pancake Range and Lunar Crater Volcanic Field on the north (Figure 1). This is the Death Valley-Pancake Range basalt zone of Vaniman et al. [1982] and Farmer et al. [1989]. Basalts from the central part of this zone in the area around Crater Flat (southern Nevada province of Menzies et al. [1983]) are among the most isotopically enriched in the region ${ }^{87} \mathrm{Sr} /{ }^{86} \mathrm{Sr} \sim 0.707, \varepsilon_{\mathrm{Nd}}<-8.5$ [see Farmer et al., 1989; Livaccari and Perry, 1993]) and have all of the major and trace element features that characterize basaltic rocks derived from the lithospheric mantle (hypersthene-normative with low $\mathrm{FeO}^{*}, \mathrm{TiO}_{2}, \mathrm{Rb} / \mathrm{Ba}$, and $\mathrm{Ti} / \mathrm{Hf}$ and high $\mathrm{La} / \mathrm{Ta}$ and $\mathrm{Ba} / \mathrm{Nb}$ [see Fitton et al., 1988]). In contrast, basaltic rocks from the northern end of the zone, in the Reveille and Pancake ranges (including the Lunar Crater Volcanic Field), are isotopically depleted $\left({ }^{87} \mathrm{Sr} / 86 \mathrm{Sr} \sim 0.7035, \varepsilon_{\mathrm{Nd}}>+3\right.$ [see Farmer et al., 1989; Foland and Bergman, 1992]) and have major and trace element features like average ocean island basalt (nephelinenormative with high $\mathrm{FeO}^{*}, \mathrm{TiO}_{2}, \mathrm{Ti} / \mathrm{Hf}$, and $\mathrm{Rb} / \mathrm{Ba}$ and low 


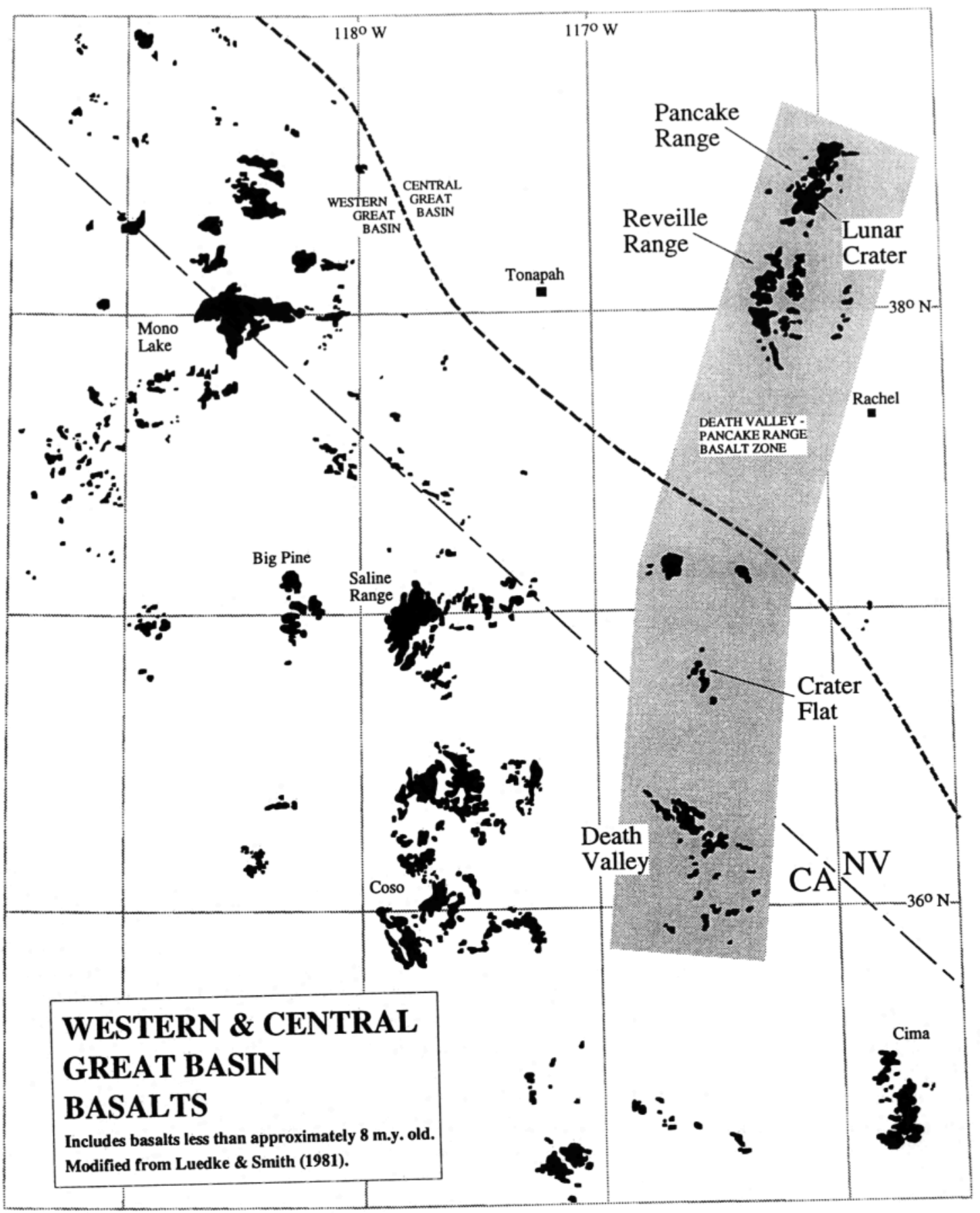

Figure 1. Distribution of basaltic volcanic rocks less than approximately $8 \mathrm{~m} . \mathrm{y}$. old in the western and central Great Basin of central and southwestern Nevada and southeastern California. Death Valley-Pancake Range basalt zone from Vaniman et al. [1982] and Farmer et al. [1989]. Modified from Luedke and Smith $[1981$.

$\mathrm{La} / \mathrm{Ta}$ and $\mathrm{Ba} / \mathrm{Nb}$ [see Fitton et al., 1988, 1991]). Basalts from the Reveille and Pancake range area are generally regarded as the asthenospherically derived end-member in the region [e.g., Fitton et al., 1988; Farmer et al., 1989].

In this paper we examine the geology and geochemistry of Pliocene age mafic volcanic rocks in the Reveille Range (Figure 1). We compare the Pliocene age Reveille Range rocks to Pleistocene age basaltic rocks from the Lunar Crater Volcanic field to the north [Bergman, 1982; Lum et al., 1989;
Foland and Bergman, 1992] and from the Crater Flat area to the south [Vaniman et al., 1982; Farmer et al., 1989; Bradshaw and Smith, 1994]. Two broadly different themes are developed. First, the data are interpreted within the context of a changing source chemistry for the Pliocene volcanic rocks, with emphasis on the addition of a crustal component to the oldest of the basalts in the Reveille Range area. Second, the data are interpreted in the context of volcanic field evolution, with 


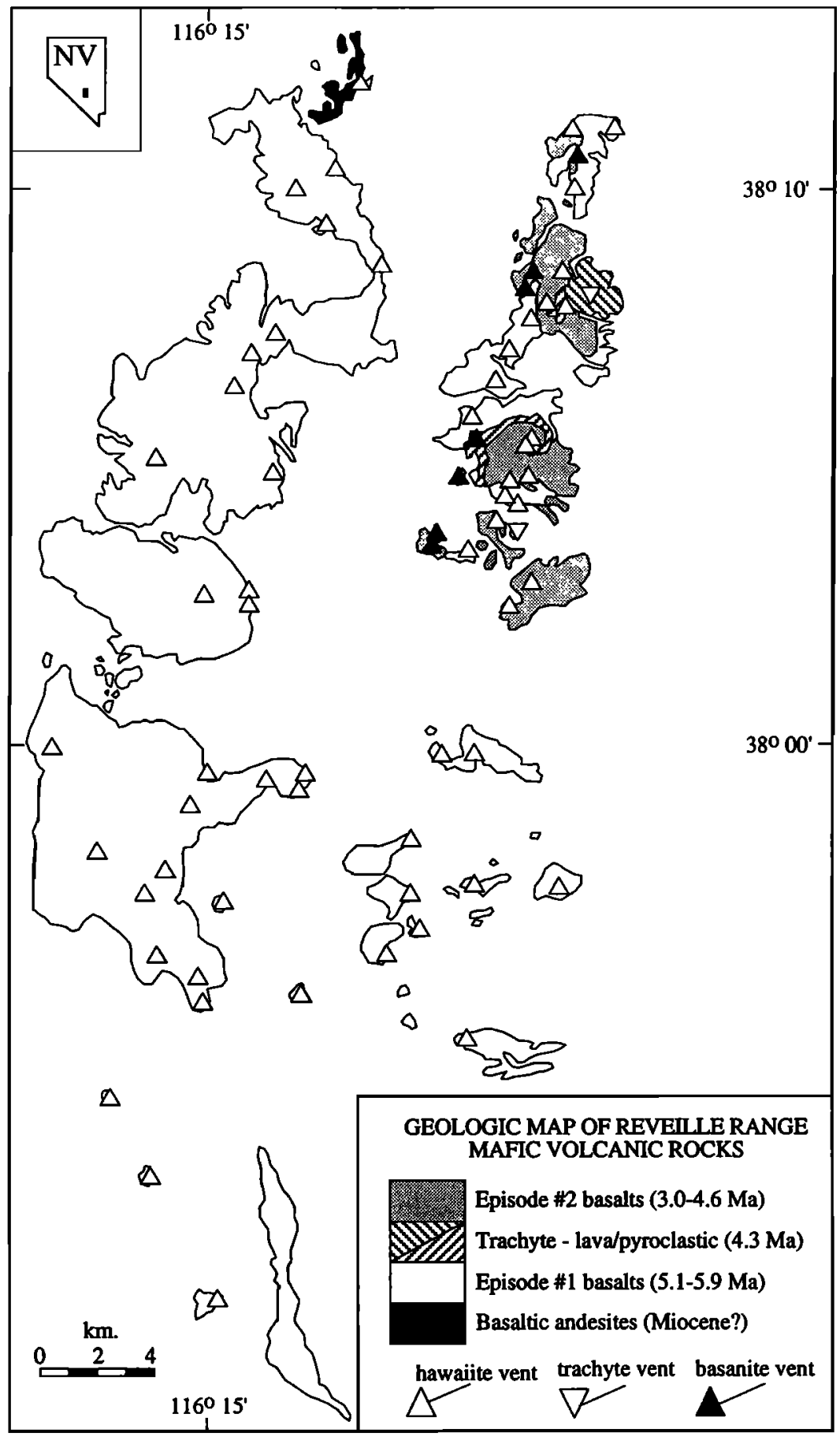

Figure 2. Geologic map of Pliocene volcanic rocks in the Reveille Range of south central Nevada (see also Figure 1). Mapping is modified slightly from that of Naumann et al. [1991]. See also Martin and Naumann [1995].

emphasis on time-space-compositional trends as they relate to magma evolution in the mantle and crust.

\section{Location, Volcanic Stratigraphy, and Petrography}

Pliocene and Pleistocene age basalts of the Reveille Range and Pancake Range (including the Lunar Crater Volcanic Field) constitute the largest volume of Late Cenozoic mafic volcanic rocks in the central Great Basin of the western United States. This area lies along the axis of geophysical symmetry outlined by Eaton et al. [1978] for the central Great Basin, and is isolated from the well-developed volcanic fields of the Sierran Province/Western Great Basin to the west, and the transition zone/Colorado Plateau to the east [Leeman, 1970, 1982; Menzies et al., 1983; Fitton et al., 1988].

Geologic mapping and $\mathrm{K}-\mathrm{Ar}$ dating in the Reveille Range and adjacent areas [Naumann et al., 1991; Martin and Naumann, 
Table 1. Rock Names, Partial Norms, Phenocryst Assemblages, and Locations for Reveille Range Samples

\begin{tabular}{|c|c|c|c|c|c|c|c|}
\hline Sample & Rock Name & neph* & hyp* & Phenocrysts $\dagger$ & Latitude North & Longitude West & Elevation, feet (m) \\
\hline \multicolumn{8}{|c|}{ Episode I Basalts } \\
\hline R9-1-48 & hawaiite & 0.0 & 0.0 & plag, olv, trace cpx & $38^{\circ} 9.8^{\prime}$ & $116^{\circ} 6.1^{\circ}$ & $6200(1890)$ \\
\hline R9-3-60 & hawaiite & 0.5 & 0.0 & plag, olv & $37^{\circ} 54.4^{\prime}$ & $116^{\circ} 7.2^{\prime}$ & 6690 (2039) \\
\hline R9-4-61 & hawaiite & 0.4 & 0.0 & plag, olv & $37^{\circ} 59.1^{\prime}$ & $116^{\circ} 6.9^{\prime}$ & $6200(1890)$ \\
\hline R8-1-4 & hawaiite & 3.4 & 0.0 & plag, olv & $38^{\circ} 4.0^{\prime}$ & $116^{\circ} 7.7$ & $6340(1932)$ \\
\hline R8-1-17 & hawaiite & 1.8 & 0.0 & plag, olv & $38^{\circ} 4.3^{\prime}$ & $116^{\circ} 7.5^{\prime}$ & $6100(1859)$ \\
\hline R9-1-56 & hawaiite & 0.0 & 5.4 & plag, olv, trace bio, cpx & $38^{\circ} 10.6^{\circ}$ & $116^{\circ} 5.6^{\prime}$ & $5280(1609)$ \\
\hline R0-1-73 & hawaiite & 0.0 & 4.1 & plag, olv & $38^{\circ} 4.7^{\circ}$ & $116^{\circ} 13.1^{\prime}$ & $6950(2118)$ \\
\hline R8-1-37 & hawaiite & 1.0 & 0.0 & plag, olv, cpx & $38^{\circ} 6.2^{\prime}$ & $116^{\circ} 8.2^{\prime}$ & $5920(1804)$ \\
\hline R8-1-7 & hawaiite & 3.5 & 0.0 & plag, olv & $38^{\circ} 3.7$ & $116^{\circ} 7.9^{\circ}$ & $5980(1823)$ \\
\hline R8-1-25 & hawaiite & 0.6 & 0.0 & plag, olv, trace bio & $38^{\circ} 3.1^{\circ}$ & $116^{\circ} 8.6^{\circ}$ & $5800(1768)$ \\
\hline R9-2-59 & hawaiite & 3.0 & 0.0 & plag, olv & $37^{\circ} 57.3^{\prime}$ & $116^{\circ} 6.0^{\circ}$ & $5800(1768)$ \\
\hline R8-1-14 & hawaiite & 0.0 & 4.2 & plag, olv & $38^{\circ} 4.0^{\prime}$ & $116^{\circ} 6.8^{\prime}$ & $5500(1676)$ \\
\hline R0-1-77 & hawaiite & 0.0 & 8.7 & plag, olv & $37^{\circ} 50.7^{\prime}$ & $116^{\circ} 12.9^{\prime}$ & $6000(1829)$ \\
\hline R8-1-29 & hawaiite & 0.1 & 0.0 & plag, olv & $38^{\circ} 5.6^{\circ}$ & $116^{\circ} 8.7$ & $6000(1829)$ \\
\hline R8-1-39 & hawaiite & 2.3 & 0.0 & plag & $38^{\circ} 6.9^{\prime}$ & $116^{\circ} 7.6^{\prime}$ & $5860(1786)$ \\
\hline R8-1-28 & hawaiite & 2.2 & 0.0 & plag, olv, oxd & $38^{\circ} 5.7$ & $116^{\circ} 8.1^{\prime}$ & $5650(1722)$ \\
\hline R9-1-66 & hawaiite & 0.3 & 0.0 & plag, trace olv & $38^{\circ} 9.6^{\circ}$ & $116^{\circ} 11.7^{\prime}$ & $6200(1890)$ \\
\hline \multicolumn{8}{|c|}{ Episade 2 Basalts } \\
\hline R8-1-27 & basanite & 9.4 & 0.0 & cpx, olv, oxd & $38^{\circ} 3.2^{\prime}$ & $116^{\circ} 9.4^{\circ}$ & $6472(1973)$ \\
\hline R8-1-23 & basanite & 9.3 & 0.0 & cpx, olv, oxd & $38^{\circ} 3.4^{\prime}$ & $116^{\circ} 9.3^{\prime}$ & $6320(1926)$ \\
\hline R8-1-26 & basanite & 10.1 & 0.0 & cpx, olv, oxd & $38^{\circ} 3.2^{\prime}$ & $116^{\circ} 9.7^{\prime}$ & $6280(1914)$ \\
\hline R8-1-22 & basanite & 8.7 & 0.0 & cpx, olv, oxd & $38^{\circ} 3.5^{\prime}$ & $116^{\circ} 9.3^{\prime}$ & $6500(1981)$ \\
\hline R8-1-11 & basanite & 10.6 & 0.0 & cpx, olv, oxd & $38^{\circ} 4.5^{\prime}$ & $116^{\circ} 8.8^{\prime}$ & $6320(1926)$ \\
\hline R8-1-30 & basanite & 7.0 & 0.0 & cpx, olv, plag, oxd & $38^{\circ} 5.2^{\prime}$ & $116^{\circ} 8.4^{\prime}$ & $6030(1838)$ \\
\hline R9-1-47 & basanite & 6.4 & 0.0 & olv & $38^{\circ} 10.4^{\prime}$ & $116^{\circ} 6.4^{\prime}$ & $5320(1622)$ \\
\hline R9-1-55 & basanite & 6.1 & 0.0 & plag, olv, oxd & $38^{\circ} 8.2^{\prime}$ & $116^{\circ} 7.7^{\prime}$ & $5540(1689)$ \\
\hline R8-1-13 & hawaiite & 0.0 & 0.1 & plag, olv, cpx, oxd & $38^{\circ} 4.4^{\prime}$ & $116^{\circ} 7.3^{\prime}$ & $6120(1865)$ \\
\hline R9-1-46 & hawaiite & 3.1 & 0.0 & olv, plag & $38^{\circ} 10.5^{\prime}$ & $116^{\circ} 6.6^{\prime}$ & $5455(1663)$ \\
\hline R8-1-32 & hawaiite & 0.0 & 0.4 & plag, olv & $38^{\circ} 2.2^{\prime}$ & $116^{\circ} 7.0^{\circ}$ & $5580(1701)$ \\
\hline R9-1.44 & hawaiite & 2.1 & 0.0 & plag, cpx, oxd, olv & $38^{\circ} 7.1^{\prime}$ & $116^{\circ} 6.0^{\circ}$ & $5300(1615)$ \\
\hline R8-1-12 & hawaiite & 0.4 & 0.0 & olv, plag, cpx, oxd & $38^{\circ} 4.25^{\circ}$ & $116^{\circ} 7.0^{\circ}$ & $5930(1807)$ \\
\hline R8-1-19 & hawaiite & 2.4 & 0.0 & plag, olv, cpx, oxd & $38^{\circ} 2.4^{\prime}$ & $116^{\circ} 7.2^{\prime}$ & $5730(1747)$ \\
\hline R8-1-6 & hawaiite & 3.7 & 0.0 & plag, olv, oxd, cpx & $38^{\circ} 4.7^{\prime}$ & $116^{\circ} 7.6^{\prime}$ & $6160(1878)$ \\
\hline R8-1-18 & hawaiite & 3.0 & 0.0 & plag, cpx, olv, oxd & $38^{\circ} 4.4^{\prime}$ & $116^{\circ} 7.4^{\prime}$ & $6240(1902)$ \\
\hline $28-1-1$ & hawaiite & 3.2 & 0.0 & plag, olv, oxd, cpx & $38^{\circ} 3.6^{\prime}$ & $116^{\circ} 8.0^{\prime}$ & 6000 (1829) \\
\hline \multicolumn{8}{|c|}{ Trachytic Rocks } \\
\hline R8-1-16 & trachy andesite & 2.6 & 0.0 & plag, kspr, oxd, cpx, trace olv & $38^{\circ} 3.5^{\prime}$ & $116^{\circ} 7.6^{\circ}$ & $5840(1780)$ \\
\hline R8-1-40 & trachy andesite & 10.6 & 0.0 & no phenocrysts & $38^{\circ} 7.7^{\prime}$ & $116^{\circ} 6.1^{\prime}$ & $5841(1780)$ \\
\hline R9-1-43 & trachyte & 8.0 & 0.0 & trace plag, ksp, cpx & $38^{\circ} 7.75^{\prime}$ & $116^{\circ} 5.3^{\prime}$ & $5240(1597)$ \\
\hline R9-1-62 & trachyte & 4.4 & 0.0 & trace plag, cpx, oxd & $38^{\circ} 7.6^{\prime}$ & $116^{\circ} 6.1^{\prime}$ & $5700(1737)$ \\
\hline R8-1-41 & trachyte & 4.4 & 0.0 & plag, kspr, cpx, oxd & $38^{\circ} 7.9^{\prime}$ & $116^{\circ} 5.7^{\prime}$ & $5380(1640)$ \\
\hline R8-1-42 & trachyte & 5.9 & 0.0 & plag, kspr, cpx, oxd & $38^{\circ} 7.6^{\circ}$ & $116^{\circ} 6.1^{\prime}$ & $5600(1707)$ \\
\hline
\end{tabular}

1995] indicate that mafic volcanism began in middle to late Miocene time with scattered enuptions of volumetrically minor basaltic andesite. The early basaltic andesites occur in the northwesternmost Reveille Range (Figure 2) and in scattered locations to the south. Near the town of Rachel (Figure 1) this unit has been dated at approximately $14 \mathrm{Ma}$ [Naumann et al., 1991]. Based on petrographic and chemical similarities, we anticipate a similar middle to late Miocene age for the early basaltic andesites in the Reveille Range. Geochemical data on the Miocene rocks are not presented here, and these rocks will not be considered further in this work.

Pliocene activity in the Reveille Range commenced with the eruption of a relatively large volume of alkalic basalt (5.1-5.9 $\mathrm{Ma}$ ), which was followed by trachytic volcanism $(4.3 \mathrm{Ma})$ and finally by a second eruptive episode of lower volume basalt (3.0-4.7 Ma, see Naumann et al. [1991] for information on dates). These map units are shown in Figure 2 and will be referred to throughout this paper as (1) the episode 1 basalts, (2) the trachytic rocks, and (3) the episode 2 basalts. Petrographic information on these units is summarized below and in Table 1.
Basalts of episode 1 are the most abundant of the Pliocene age volcanic rocks in the Reveille Range. They comprise a minimum volume of approximately $8 \mathrm{~km}^{3}$ (estimate of outcrop volume) and were erupted from -52 vents located throughout the range (Figure 2). Most episode 1 basalts contain phenocrysts of olivine and plagioclase only (25-35 modal percent), but some also contain minor phenocrysts of clinopyroxene, Fe-Ti oxide, and occasionally biotite. Large phenocrysts $(>5 \mathrm{~mm})$ and/or megacrysts $(>1 \mathrm{~cm})$ of calcic feldspar (labradorite) are also common, and these sometimes occur in glomerocrystic trains that range up to $15 \mathrm{~cm}$ in long dimension. The common presence of biotite in the groundmass of episode 1 basalts is notable. Alteration minerals include iddingsite and less commonly serpentine or bowlingite (both after olivine) and calcite.

In the northeastem Reveille Range, basalts of episode 1 are overlain by two trachytic dome-like lava flows $\left(-0.1 \mathrm{~km}^{3}\right)$ and associated pyroclastic surge deposits [see Naumann et al., 1990]. The trachytic lavas are sparsely phyric ( $<5$ modal percent) with phenocrysts of sanidine, plagioclase, greencolored clinopyroxene, Fe-Ti oxides, and occasionally apatite. 


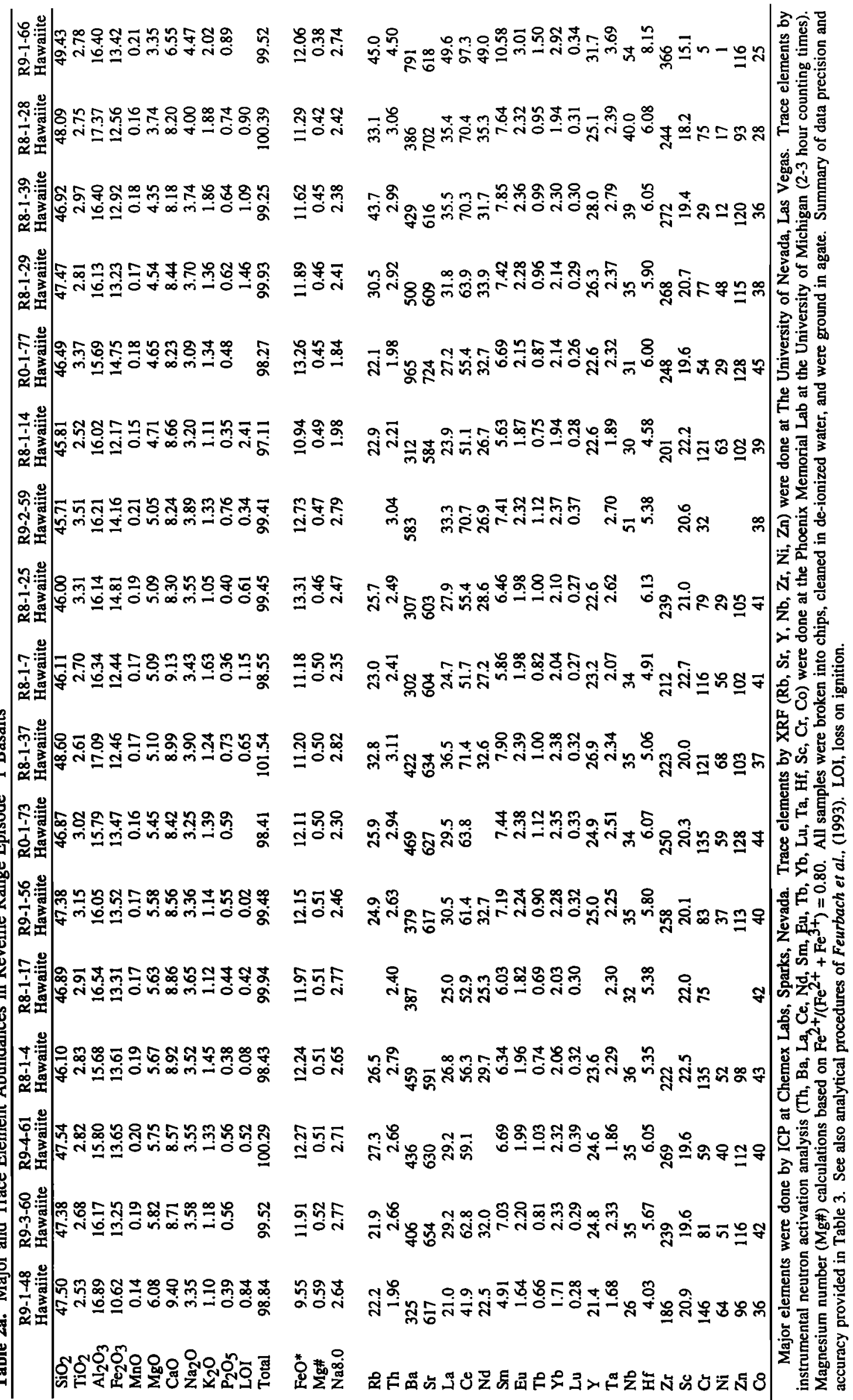




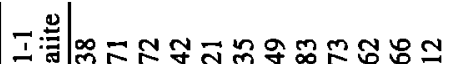

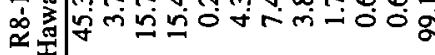
$\infty$

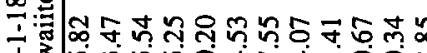

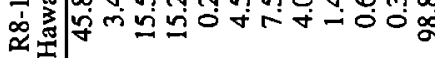

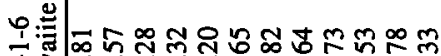

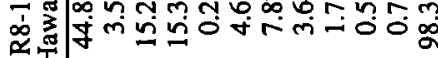
을 을

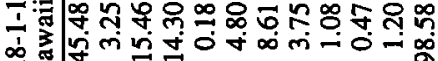
$\propto$

는

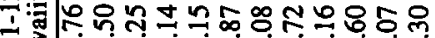

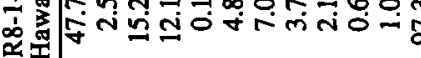

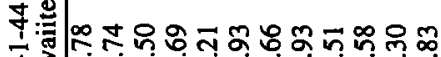

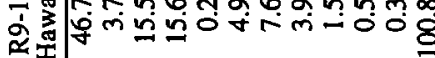

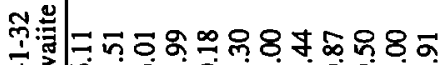

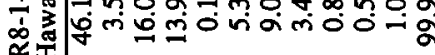

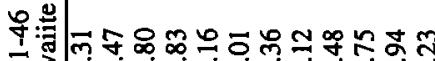

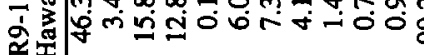

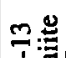

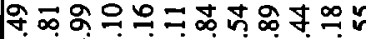

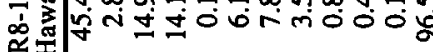

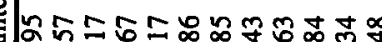

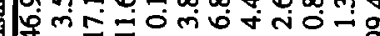

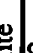

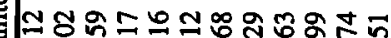

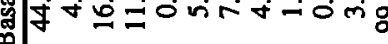

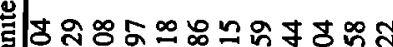

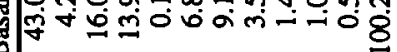

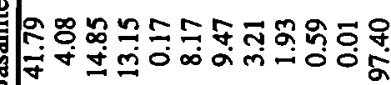

응ำ

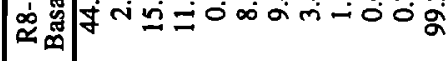

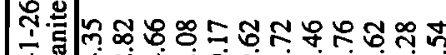

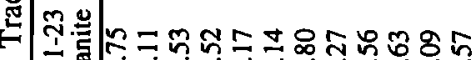

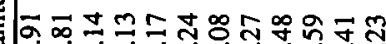
भंष

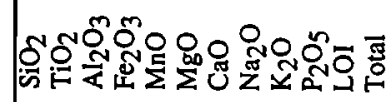

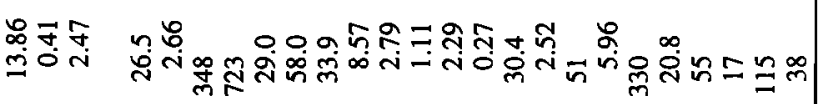

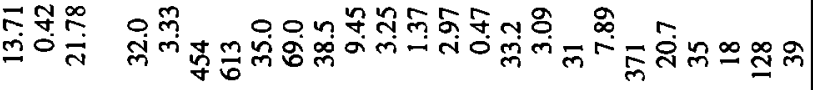

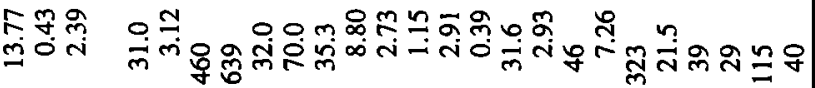

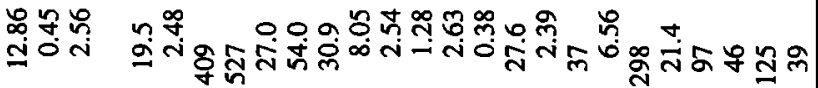

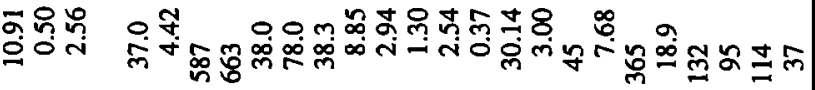

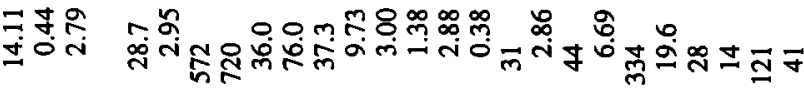

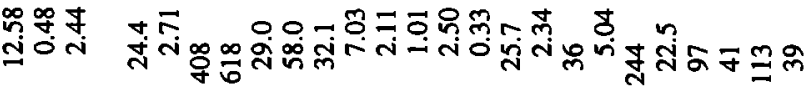

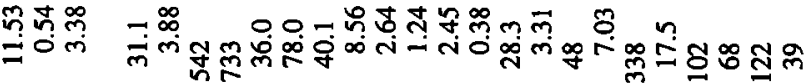

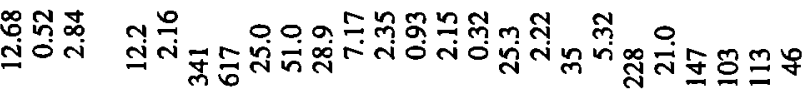

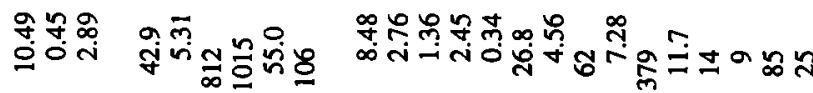

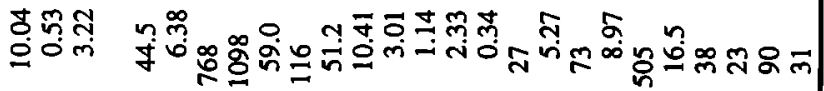

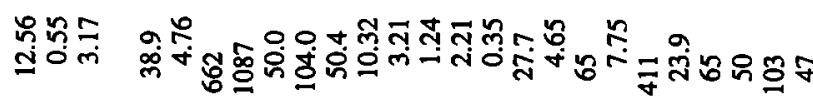

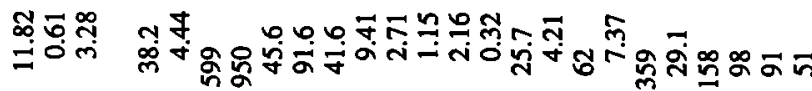

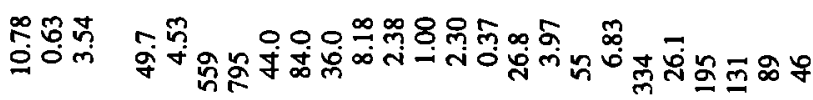

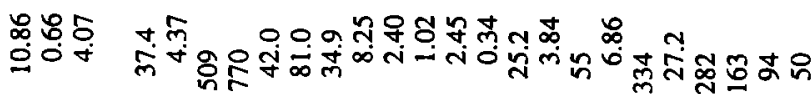

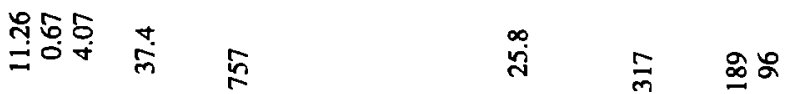

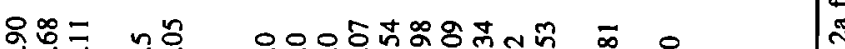

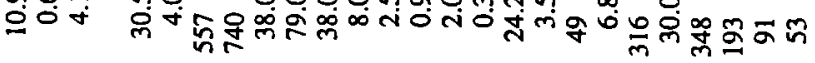

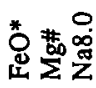


Table 2c. Major and Trace Element Abundances in Reveille Range Trachytic Rocks

\begin{tabular}{|c|c|c|c|c|c|c|}
\hline & $\begin{array}{c}\text { R8-1-16 } \\
\text { Trachy-andesite }\end{array}$ & $\begin{array}{c}\text { R8-1-40 } \\
\text { Trachy-andesite }\end{array}$ & $\begin{array}{l}\text { R9-1-43 } \\
\text { Trachyte }\end{array}$ & $\begin{array}{l}\text { R9-1-62 } \\
\text { Trachyte }\end{array}$ & $\begin{array}{l}\text { R8-1-41 } \\
\text { Trachyte }\end{array}$ & $\begin{array}{l}\text { R8-1-42 } \\
\text { Trachyte }\end{array}$ \\
\hline $\mathrm{SiO}_{2}$ & 55.77 & 55.71 & 58.92 & 59.74 & 59.83 & 60.14 \\
\hline $\mathrm{TiO}_{2}$ & 1.11 & 0.44 & 0.47 & 0.51 & 0.45 & 0.51 \\
\hline $\mathrm{Al}_{2} \mathrm{O}_{3}$ & 16.11 & 15.93 & 16.94 & 17.28 & 17.35 & 17.23 \\
\hline $\mathrm{Fe}_{2} \mathrm{O}_{3}$ & 9.82 & 6.86 & 6.74 & 7.11 & 6.85 & 7.20 \\
\hline Mno & 0.20 & 0.17 & 0.17 & 0.18 & 0.16 & 0.18 \\
\hline $\mathrm{MgO}$ & 1.20 & 0.47 & 0.52 & 0.47 & 0.28 & 0.38 \\
\hline $\mathrm{CaO}$ & 3.80 & 4.60 & 3.62 & 2.26 & 1.97 & 2.04 \\
\hline $\mathrm{Na} 2 \mathrm{O}$ & 5.53 & 5.98 & 6.25 & 6.50 & 6.22 & 6.58 \\
\hline $\mathrm{K}_{2} \mathrm{O}$ & 4.28 & 5.33 & 5.58 & 5.24 & 5.83 & 5.68 \\
\hline $\mathrm{P}_{2} \mathrm{O}_{5}$ & 0.30 & 0.17 & 0.11 & 0.24 & 0.16 & 0.18 \\
\hline LOI & 0.01 & 2.57 & 1.64 & 0.57 & 0.27 & 1.12 \\
\hline Total & 98.13 & 98.23 & 100.96 & 100.10 & 99.37 & 101.24 \\
\hline $\mathrm{FeO}^{*}$ & 8.83 & 6.17 & 6.06 & 6.39 & 6.16 & 6.47 \\
\hline Mg\# & 0.23 & 0.15 & 0.16 & 0.14 & 0.09 & 0.12 \\
\hline $\mathbf{R b}$ & 71.2 & & 87.0 & 90.4 & & 89.6 \\
\hline Th & 8.46 & & 9.77 & 10.3 & 10.3 & \\
\hline $\mathbf{B a}$ & 849 & & 353 & 364 & 264 & \\
\hline $\mathbf{S r}$ & 308 & & 101 & 78 & & 79 \\
\hline La & 62.9 & & 73.0 & 82.3 & 72.6 & \\
\hline $\mathrm{Ce}$ & 130 & & 137 & 155 & 150 & \\
\hline Nd & 69.7 & & 64.8 & 71.4 & 60.9 & \\
\hline Sm & 14.7 & & 13.4 & 13.7 & 13.6 & \\
\hline Eu & 3.95 & & 2.30 & 2.64 & 2.46 & \\
\hline Tb & 2.37 & & 2.03 & 1.85 & 1.89 & \\
\hline $\mathrm{Yb}$ & 5.33 & & 5.11 & 4.70 & 4.32 & \\
\hline Lu & 0.75 & & 0.68 & 0.68 & 0.60 & \\
\hline $\mathbf{Y}$ & 51.9 & & 48.0 & 48.5 & & 45.9 \\
\hline $\mathbf{T a}$ & 4.85 & & 6.41 & 6.46 & 6.49 & \\
\hline $\mathrm{Nb}$ & 64 & & 84 & 88 & 90 & 76 \\
\hline Hf & 16.7 & & 18.2 & 18.8 & 18.5 & \\
\hline $\mathrm{Zr}$ & 879 & & 953 & 947 & & 814 \\
\hline Sc & 12.4 & & 5.9 & 6.5 & 5.8 & \\
\hline $\mathrm{Cr}$ & 19 & & 11 & 3 & 16 & \\
\hline $\mathrm{Ni}$ & 1 & & 1 & 1 & & 1 \\
\hline $\mathrm{Zn}$ & 129 & & 124 & 108 & & 102 \\
\hline Co & 9 & & 2 & 2 & 1 & \\
\hline
\end{tabular}

The groundmass in the trachytic rocks is dominated by feldspar, pyroxene, oxides, and colorless to pale green glass. Except for the presence of calcite in the groundmass of some samples, the trachytic rocks are mostly free of alteration minerals.

Basalts of episode 2 are the youngest volcanic rocks in the Reveille Range. They comprise a minimum volume of approximately $1 \mathrm{~km}^{3}$ and were erupted from 14 vents located only in the northeastern part of the range (Figure 2). Most episode 2 basalts contain phenocrysts of plagioclase, olivine, clinopyroxene, and Fe-Ti oxides, but some samples (which we classify below as basanites) lack phenocrysts of plagioclase. Episode 2 basalts are distinguished by the common presence of large clinopyroxene crystals (phenocrysts or megacrysts) and/or cognate xenoliths of medium-grain plagioclaseclinopyroxene-oxide gabbro. At some locations, lavas of episode 2 also contain phenocrysts and/or megacrysts of amphibole and abundant ultramafic inclusions (dunite, harzburgite). Biotite does not occur as a phenocryst phase in the episode 2 basalts and is less common and less well developed in the groundmass than in basalts of episode 1 . Alteration minerals are like those in episode 1 basalts, though calcite appears to be less common in the episode 2 samples.

\section{Geochemistry}

Major and trace element data for Reveille Range volcanic rocks are presented in Tables $2 a, 2 b$, and $2 c$. Replicate and standard analyses are in Table 3. Isotopic analyses for Reveille Range rocks are presented in Table 4, along with new isotopic data on Pleistocene-age basalts of southern Nevada Crater Flat area (trace element data for the Crater Flat samples are presented in Bradshaw and Smith, 1994).

\section{Major Elements}

Pliocene basalts of episode 1 (Table 2a) are mildly alkaline with silica-saturated and undersaturated varieties (Table 1). Episode 1 basalts have $45.7-49.4 \% \mathrm{SiO}_{2}, 1.0-2.2 \% \mathrm{~K}_{2} \mathrm{O}$, and total alkalis of $4.3-6.5 \%\left(\mathrm{~K}_{2} \mathrm{O}+\mathrm{Na}_{2} \mathrm{O}\right.$, Figure 3 and Table 2a). They are relatively high in FeO* $(9.6 \%-14.0 \%)$ and $\mathrm{TiO}_{2}$ (2.5$3.6 \%)$ and have low-to-moderate contents of $\mathrm{Al}_{2} \mathrm{O}_{3}$ (15.1$17.4 \%)$, $\mathrm{MgO}$ (2.6-6.1\%), and $\mathrm{CaO}$ (6.6-9.4\%). Normative compositions and total alkali contents indicate that the rock name "hawaiite" is appropriate for all episode 1 basalts (Table 1 and Figure 3; see also MacDonald and Katsura [1964] and Le Maitre [1989]).

Pliocene basalts of episode 2 (Table 2 b) are nearly all nepheline-normative (Table 1). On average, episode 2 basalts are therefore slightly more alkaline than episode 1 (i.e., lower $\mathrm{SiO}_{2}, \mathrm{Al}_{2} \mathrm{O}_{3}$, and $\mathrm{CaO}$ and higher $\mathrm{TiO}_{2}, \mathrm{FeO} *, \mathrm{Na}_{2} \mathrm{O}$, and $\mathrm{MgO}$ ), but the major element similarities between the stratigraphic groups are generally more striking than are their differences. One exception is the subset of episode 2 samples which are strongly undersaturated ( $>5 \%$ normative nepheline) with $<45 \%$ $\mathrm{SiO}_{2}$ and/or high total alkali contents (Table $2 \mathrm{~b}$ and Figure 3). 
Table 3. Data Precision and Accuracy

\begin{tabular}{|c|c|c|c|c|c|c|c|c|}
\hline & \multicolumn{2}{|c|}{$\begin{array}{l}\text { INAA Replicate } \\
\text { R9-1-47 }(n=4)\end{array}$} & \multicolumn{3}{|c|}{$\begin{array}{l}\text { INAA USGS Standard } \\
\text { BHVO-1 }(n=4)\end{array}$} & \multicolumn{3}{|c|}{$\begin{array}{c}\text { XRF USGS Standard } \\
\text { SCO-1 }(n=6)\end{array}$} \\
\hline & Mean ppm & Precision* & Mean ppm & Precision* & Accepted & Mean ppm & Precision* & Accepted \\
\hline Th & 6.38 & $4.1 \%$ & 1.13 & $16.3 \%$ & 1.08 & na & na & na \\
\hline $\mathrm{Ba}$ & 768 & $3.8 \%$ & 140 & $11.5 \%$ & 139 & na & na & na \\
\hline $\mathrm{Ta}$ & 5.27 & $4.8 \%$ & 1.24 & $7.6 \%$ & 1.23 & na & na & na \\
\hline $\mathrm{Hf}$ & 8.97 & $6.1 \%$ & 4.68 & $1.7 \%$ & 4.38 & na & na & na \\
\hline $\mathrm{La}$ & 62.6 & $6.1 \%$ & 15.7 & $2.8 \%$ & 15.8 & na & na & na \\
\hline $\mathrm{Ce}$ & 123 & $4.0 \%$ & 39.4 & $11.4 \%$ & 39.0 & na & na & na \\
\hline Sm & 11.0 & $5.8 \%$ & 6.47 & $2.3 \%$ & 6.20 & na & na & na \\
\hline $\mathrm{Eu}$ & 3.19 & $3.0 \%$ & 1.97 & $5.9 \%$ & 2.06 & na & na & na \\
\hline $\mathrm{Tb}$ & 1.21 & $2.3 \%$ & 0.91 & $12.3 \%$ & 0.96 & na & na & na \\
\hline $\mathrm{Yb}$ & 2.47 & $2.9 \%$ & 1.81 & $3.8 \%$ & 2.02 & na & na & na \\
\hline Lu & 0.36 & $3.4 \%$ & 0.28 & $19.8 \%$ & 0.40 & na & na & na \\
\hline Sc & 16.5 & $5.7 \%$ & 30.9 & $1.2 \%$ & 31.8 & na & na & na \\
\hline $\mathrm{Cr}$ & 37.8 & $5.1 \%$ & 293. & $2.5 \%$ & 289 & na & na & na \\
\hline Co & 31.5 & $10.4 \%$ & 43.2 & $2.1 \%$ & 45.0 & na & na & na \\
\hline $\mathrm{Rb}$ & na & na & na & na & na & 115 & $4.2 \%$ & 112 \\
\hline $\mathrm{Sr}$ & na & na & na & na & na & 168 & $6.6 \%$ & 174 \\
\hline $\mathrm{Nb}$ & na & na & na & na & na & 12.4 & $2.2 \%$ & 11.0 \\
\hline$Y$ & na & na & na & na & na & 34.8 & $2.2 \%$ & 26.0 \\
\hline$\hat{\mathbf{Z}}_{\mathbf{r}}$ & na & na & na & na & na & 157 & $10.2 \%$ & 160 \\
\hline $\mathrm{Ni}$ & na & na & na & na & na & 38 & $17.8 \%$ & 27 \\
\hline
\end{tabular}

*Analytical precision is two standard deviations expressed as a percentage of the mean for repeat analyses of samples and standards.

Other values are in parts per million. Accepted values for the primary INAA standard (NIST 1633 fly-ash) are Th (24.7 ppm), Ba (1420), Ta (2.00), Hf (7.40), La (84.0), Ce (175), Sm (17.0), Eu (3.70), Tb (2.50), Yb (7.40), Lu (1.12), Sc (39.0), Cr (196), Co (43.0).

These lavas are petrographically distinct in that plagioclase is generally not an abundant phenocryst phase (Table 1). These features justify the rock name "basanite" to distinguish them from the less alkaline and more plagioclase-phyric hawaite basalts.

The Reveille Range trachytic rocks (55-62\% $\mathrm{SiO}_{2}$ ) have total alkalis of $9.8-12.3 \%\left(\mathrm{Na}_{2} \mathrm{O}+\mathrm{K}_{2} \mathrm{O}\right)$ and contain $3-11 \%$ normative nepheline (Figure 3 and Table 1c). Compared to the Reveille Range basalts, the trachytic rocks have $\mathrm{K}_{2} \mathrm{O}$ contents that are higher by a factor of $4\left(\mathrm{~K}_{2} \mathrm{O}=4.3-5.8 \%\right)$. The trachytic rocks are moderate to high in $\mathrm{Al}_{2} \mathrm{O}_{3}(15.9-17.4 \%)$ and $\mathrm{FeO}^{*}$ (6.7-9.8\%), variably low in $\mathrm{TiO}_{2}(0.44-1.11 \%)$ and $\mathrm{CaO}(2.0-$ $4.6 \%)$, and very low in $\mathrm{MgO}(0.4-1.2 \%)$. The Reveille Range trachytic rocks resemble tristanites and other evolved rocks of the alkaline ocean island basalt (OIB) igneous series [e.g., Wilkinson, 1974].

\section{Incompatible Elements}

Incompatible element concentrations (Tables $2 a-2 c$ ) and interelement ratios are broadly similar for episode 1 and episode 2 hawaiites, episode 2 basanites, average OIB, and for Pleistocene age basalts of the Lunar Crater Volcanic field. This is clear from the average compositions plotted on extended mid-ocean ridge basalt (MORB)-normalized incompatible èlement diagrams (Figure 4), and from ratio-ratio plots of all the available samples (Figure 5). The similarity of the Reveille Range and Lunar Crater data to average OIB contrasts with that of Pleistocene age basalts from Crater Flat, which have higher concentrations of $\mathrm{Ba}, \mathrm{Th}$, and light rare earth elements (LREE) but lower relative concentrations of high field strength elements (HFSE), especially $\mathrm{Ta}$ and Ti (Figures 4 and 5).

Important differences among Reveille Range basalts are revealed by their incompatible and compatible element concentrations. Nearly all the basanites have higher concentrations of $\mathrm{Sr}, \mathrm{La}, \mathrm{Th}, \mathrm{Zr}$, and $\mathrm{Ta}$ (relative to $\mathrm{MgO}$ ) than the hawaiites (Figure 6), and in this way the episode 2 basanites are similar to the youngest basalts of the Lunar Crater Volcanic Field.
An extended plot of OIB-normalized concentrations (Figure 7) shows again that the Reveille Range basanites have relatively high concentrations of incompatible elements compared to the hawaiites. Episode 2 hawaiites have, on average, higher incompatible element concentrations than episode 1 hawaiites, but these differences are small compared to the distinctive basanites. Figure 7 also points out the broad similarity in interelement ratios among all Reveille Range basalts. The only clear exception to this is the relative concentration of $\mathrm{Pb}$ (i.e., $\mathrm{Pb} / \mathrm{La}, \mathrm{Pb} / \mathrm{Ce}$ ) which is substantially higher in episode 1 hawaiites than in any of the episode 2 samples (hawaiites or basanites).

The rare earth element characteristics of the Reveille Range basalts are consistent with other incompatible element features. All of the Reveille Range basalts show an overall light REE-enriched pattern (Figure 8) with uniformly low abundances of heavy REE ( $\mathrm{Yb}, \mathrm{Lu}$ ) at approximately 8 times chondritic. On average, the episode 2 basanites have the highest concentrations of light REE at 100-155 times chondritic. The episode 1 hawaiites have light REE concentrations of 56-130 times chondrites, and the episode 2 hawaiites fall within a relatively restricted compositional range with light REE at 66-100 times chondrites (see also $\mathrm{La} / \mathrm{Yb}$ versus $\mathrm{MgO}$ in Figure 6).

In the Reveille Range trachytic rocks, concentrations of the most incompatible elements are significantly higher than in the associated basalts (Figure 7). The highest concentrations are in $\mathrm{Zr}(\sim 926 \mathrm{ppm}), \mathrm{Hf}(\sim 18 \mathrm{ppm}), \mathrm{Rb}(\sim 83 \mathrm{ppm})$, and $\mathrm{K}_{2} \mathrm{O}$ (5.4 wt \%) which range between 2.5 and 3.8 times the concentrations in the basalts. Concentrations of $\mathrm{La}(73 \mathrm{ppm})$, $\mathrm{Nb}$ (82 ppm), Y (49 ppm), and $\mathrm{Yb}$ (4.8 ppm) are 1.4-2.4 times higher than in the basalts. The trachytic rocks have negative Eu anomalies $\left(\mathrm{Eu} / \mathrm{Eu}^{*}=0.54-0.83\right)$, but their REE patterns are otherwise parallel to those of the basalts at higher concentrations (Figure 9). In contrast, concentrations of Ba in the trachytic rocks $(-420 \mathrm{ppm})$ are similar to or slightly lower than in the basalts, and concentrations of $\mathrm{Sr}(\sim 160), \mathrm{P}_{2} \mathrm{O}_{5}$ $(0.19 \mathrm{wt} \%)$, and $\mathrm{TiO}_{2}(0.56 \mathrm{wt} \%)$ are all substantially lower (Table 2 and Figure 7). 


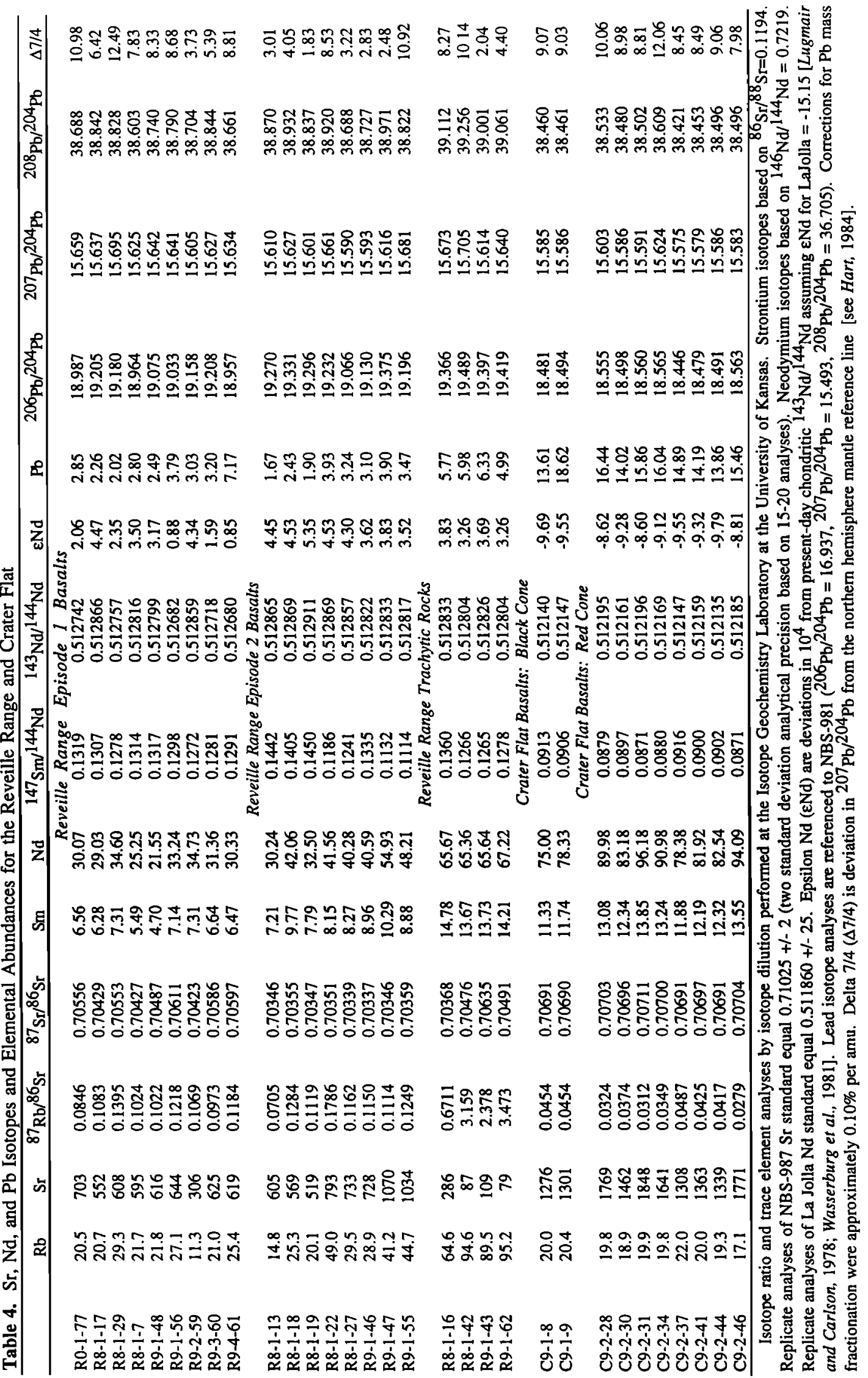




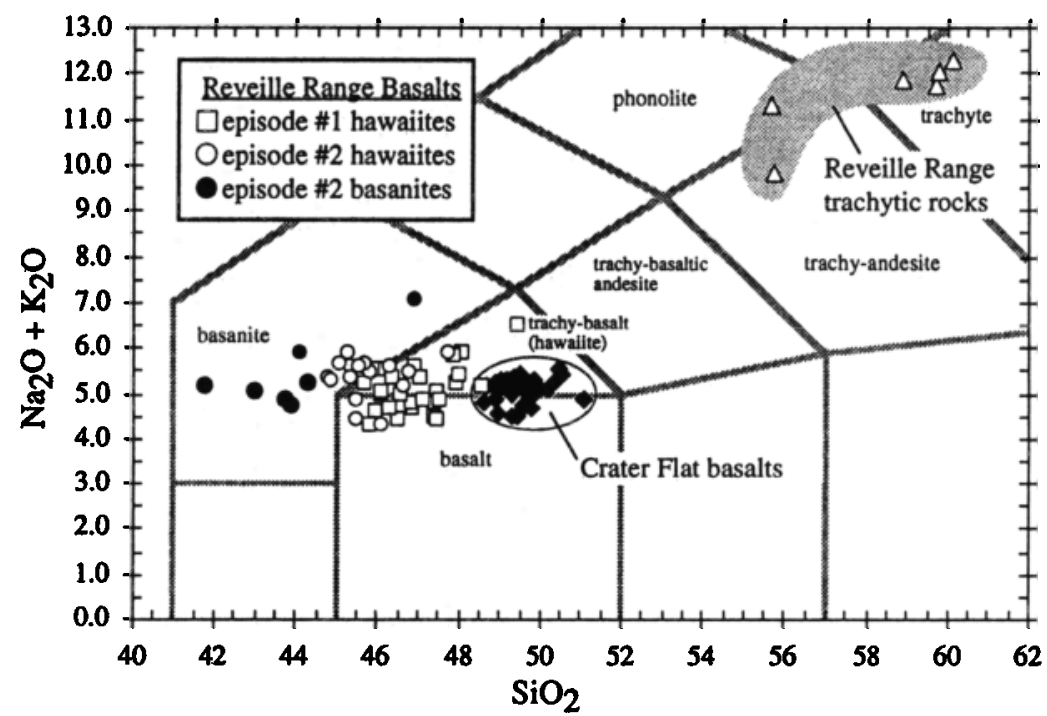

Figure 3. Total alkalis versus $\mathrm{SiO}_{2}$ for Pliocene age volcanic rocks of the Reveille Range compared with Pleistocene age basalts from Crater Flat and the Lunar Crater Volcanic Field. Reveille Range rocks designated here as basanites (solid circles) are distinguished by their relatively low $\mathrm{SiO}_{2}$ and high alkali contents and by petrographic features, especially the absence of plagioclase phenocrysts (see text and Table 1). Reveille Range data are from Table 2 and unpublished University of Nevada, Las Vegas, data. Crater Flat samples are Red Cone and Black Cone analyses from Bradshaw and Smith [1994]. Lunar Crater Volcanic Field data are from Bergman [1982] and Kargel [1987].

\section{AVERAGE BASALT COMPOSITIONS}
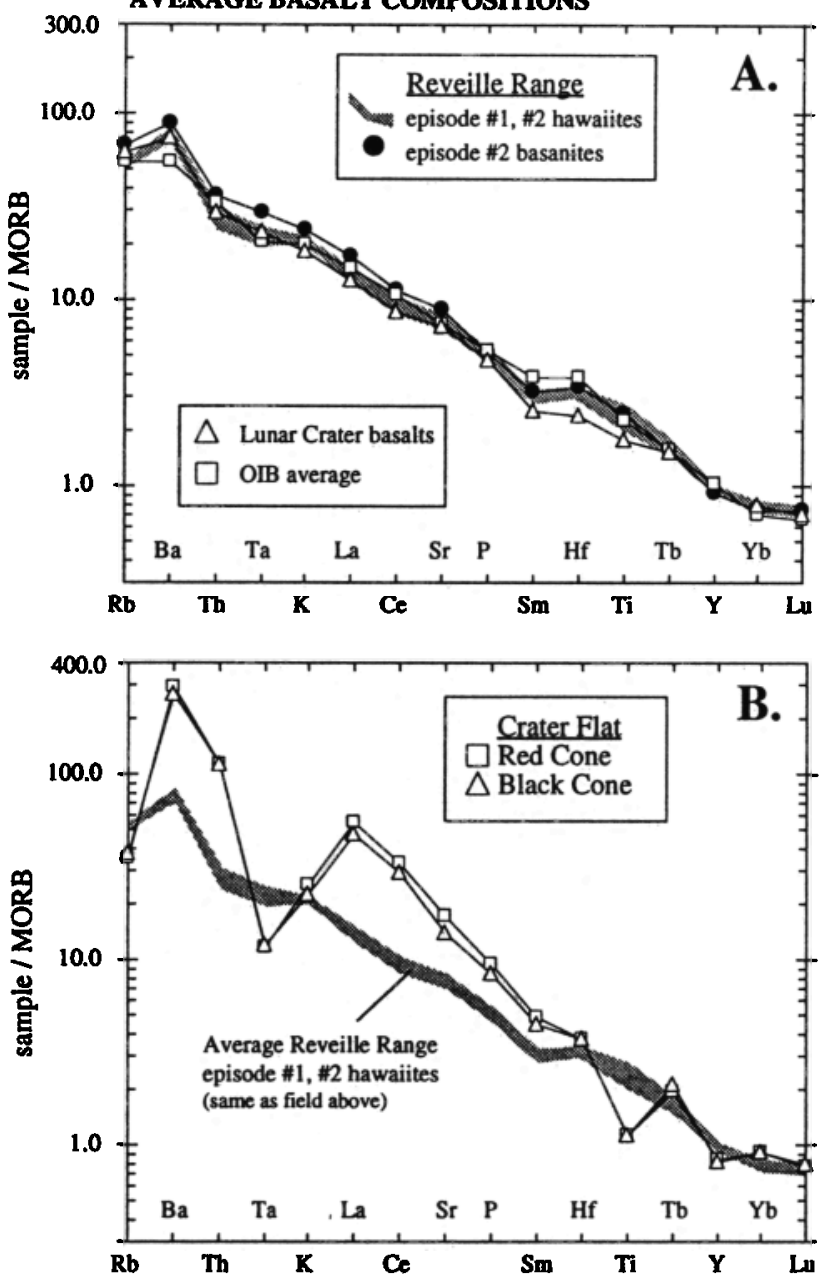

\section{Sr, Nd, and Pb Isotopes}

Isotopic compositions of episode 1 and episode 2 basalts are somewhat variable considering the overall similarity in their incompatible element features. Episode 1 hawaiites show a wide range in ${ }^{87} \mathrm{Sr} /{ }^{86} \mathrm{Sr}(0.7043-0.7061)$, whereas the range in episode 2 (basanites and hawaiites) is more restricted $(0.7035-0.7037$, Figure 10$)$. Neodymium isotopes are also more variable in basalts of episode 1 than episode 2, though the differences are not as great as for Sr (Figure 10). A similar pattern can be seen in the $\mathrm{Pb}$ isotope data; most of the episode 2 basalts form a linear trend immediately above the manfle reference line at high $206 \mathrm{~Pb} / 204 \mathrm{~Pb}(\sim 19.2)$, whereas the episode 1 basalts scatter from the mantle trend toward high ${ }^{207} \mathrm{~Pb} / 204 \mathrm{~Pb}$ and high $\Delta 7 / 4 \mathrm{~Pb}$ (Figure 11). The trachytic rocks in the Reveille Range are also variable (high ${ }^{87} \mathrm{Sr} / 86 \mathrm{Sr}$ and ${ }^{207} \mathrm{~Pb} / 204 \mathrm{~Pb}$ ) and in this regard are like the episode 1 hawaiites (Figures 10 and 11).

Figure 4. MORB-normalized incompatible element diagram. Normalizing values and plotting order are from Sun and McDonough [1989]. (a) Comparison of average Pliocene age Reveille Range hawaiites (episode 1 and episode 2) to the average Pliocene age basanite, average Pleistocene age basalt from the Lunar Crater Volcanic Field [Bergman, 1982; Kargel, 1987], and average ocean island basalt (OIB from Sun and McDonough [1989]). (b) Comparison of average Pliocene age Reveille Range hawaiites (episode 1 and episode 2) to the average Red Cone and Black Cone analyses from Crater Flat [Bradshaw and Smith, 1994]. Notice the similarity among OIB, Lunar Crater, and all the Reveille Range data (Figure 4a), and contrast those relatively smooth patterns with the spiky pattern produced by the Crater Flat data (Figure 4b). 

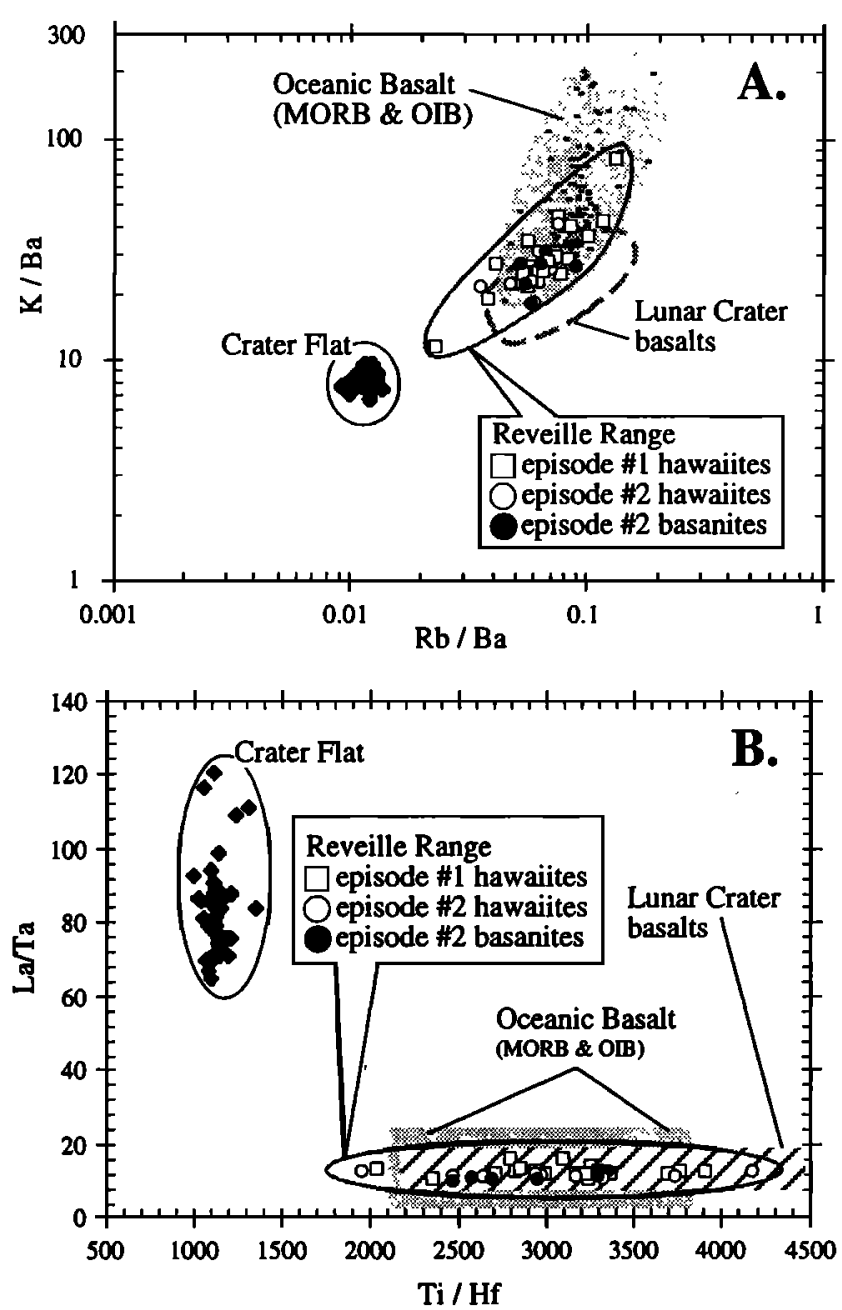

Figure 5. Incompatible element ratio-ratio plots comparing Pliocene Reveille Range basalts to Pleistocene basalts from Crater Flat and the Lunar Crater Volcanic Field (locations in Figure 1). (a) $\mathrm{K} / \mathrm{Ba}$ versus $\mathrm{Rb} / \mathrm{Ba}$; note the similarity of the Reveille Range the Lunar Crater basalts to oceanic basalt and the distinctive character (high $\mathrm{Ba}$ relative to $\mathrm{Rb}$ and $\mathrm{K}$ ) of the Crater Flat data. (b) $\mathrm{La} / \mathrm{Ta}$ versus Ti/Hf; note again the similarity of the Reveille Range the Lunar Crater basalts to oceanic basalt and the distinctive character (low relative Ti and Ta) of the Crater Flat data. Reveille Range data are from Table 1. Lunar Crater data are from Bergman [1982] and Kargel [1987]. Crater Flat data are Red Cone and Black Cone analyses from Bradshaw and Smith [1994]. Oceanic basalt data are from Hofmann and White [1983]. Data regarded as "suspect" by Hofmann and White (in parentheses in their Table 1) are excluded.

\section{Petrogenesis}

\section{Asthenospheric Basalts With a Component From the Upper Crust}

Pliocene age basalts of episode 1 and episode 2 in the Reveille Range have incompatible element concentrations and interelement ratios that are nearly identical to those of average OIB (Figures 5 and 6). The incompatible element data therefore indicate that the predominant source for Pliocene basalts in the Reveille Range was asthenospheric mantle [see also Fitton et al., 1988]. The presence of the OIB-type incompatible element signature in Pleistocene age basalts of the Lunar Crater Volcanic field [Bergman, 1982; Foland et al., 1987; Lum et al., 1989] indicates that the mantle source of mafic volcanism in this part of central Nevada has remained largely unchanged for the past 5-6 Myr.

In general, the isotopic data for these rocks are consistent with the incompatible element data and the asthenospheric source interpretation. The episode 2 samples form a tight cluster around ${ }^{87} \mathrm{Sr} / 86 \mathrm{Sr} \sim 0.7035$ and $\varepsilon_{\mathrm{Nd}^{-+4}}$, and most of the $\mathrm{Pb}$ isotopes for the episode 2 rocks fall on a trend immediately above and parallel to the northern hemisphere reference line (Figures 10 and 11). Isotopic characteristics of Pleistocene age basalts in the Lunar Crater Volcanic field [Bergman, 1982; Foland et al., 1983; Foland and Bergman, 1992] are like those of episode 2 and are thus consistent with the asthenospheric source interpretation.

There are, however, isotopic features of the episode 1 hawaiites (5-6 Ma) that probably do not reflect geochemical variation within the asthenospheric source. Specifically, the wide variation in $\mathrm{Sr}$ isotopes relative to $\varepsilon_{\mathrm{Nd}}$ in the episode 1 samples contrasts with the tight cluster of the episode 2 data. The flat trend in the episode 1 data (shallow negative slope) on the $\mathrm{Nd}-\mathrm{Sr}$ isotope diagram (Figure 10) is toward a high $\mathrm{Sr} / \mathrm{Nd}$ component and, in this regard, is unlike well-correlated trends that are generally seen in largely mantle-derived volcanic systems (e.g., southem Nevada area basalts in Figure 10). The absence of this radiogenic Sr signature from the younger basalts in the area (episode 2, Lunar Crater) argues that is not a feature of the asthenospheric source and must therefore have been acquired when episode 1 basalts moved through the lithosphere.

The high ${ }^{87} \mathrm{Sr} / 86 \mathrm{Sr}$ and high $\mathrm{Sr} / \mathrm{Nd}$ features of the radiogenic component in the episode 1 hawaiites are relatively well constrained by the data array and concave-downward curvature of the mixing line and are similar to Sr-Nd components in modem marine sediment and/or average upper crust (Figure 12). The high $\mathrm{Sr} / \mathrm{Nd}$ requirement is particularly important because it disqualifies enriched lithospheric mantle (or basalts from such mantle) as likely sources of this component (Figure 12). We believe therefore that the episode 1 basalts acquired an upper crustal component through assimilation of wall rock in a shallow magma chamber. Foland et al. [1991] and Foland and Bergman [1992] showed that $\mathrm{Sr}$ and Nd isotopes in basalts of the Reveille Range and Pancake Range-Lunar Crater Volcanic Field are strongly correlated with oxygen isotopes $\left(\delta^{18} \mathrm{O}\right)$, and they too argue for assimilation of crust by the older (Pliocene age) rocks in the area.

\section{Case for Carbonate Assimilation in Episode 1 Hawaiites}

The isotopic data presented here and from Foland and Bergman [1992] indicate that the crustal contaminant in the episode 1 basalts had high ${ }^{87} \mathrm{Sr} / 86 \mathrm{Sr}, \mathrm{Sr} / \mathrm{Nd}$, and $\delta^{18} \mathrm{O}$. It must additionally have had relatively low concentrations of most other incompatible elements, because although the episode 1 lavas have relatively radiogenic $\mathrm{Sr}$, their overall incompatible element profile is nearly the same as that for the episode 2 and Lunar Crater samples (Figures 5 and 6).

One possibility is that the episode 1 lavas were contaminated by limestone or some other carbonate-rich rock. 

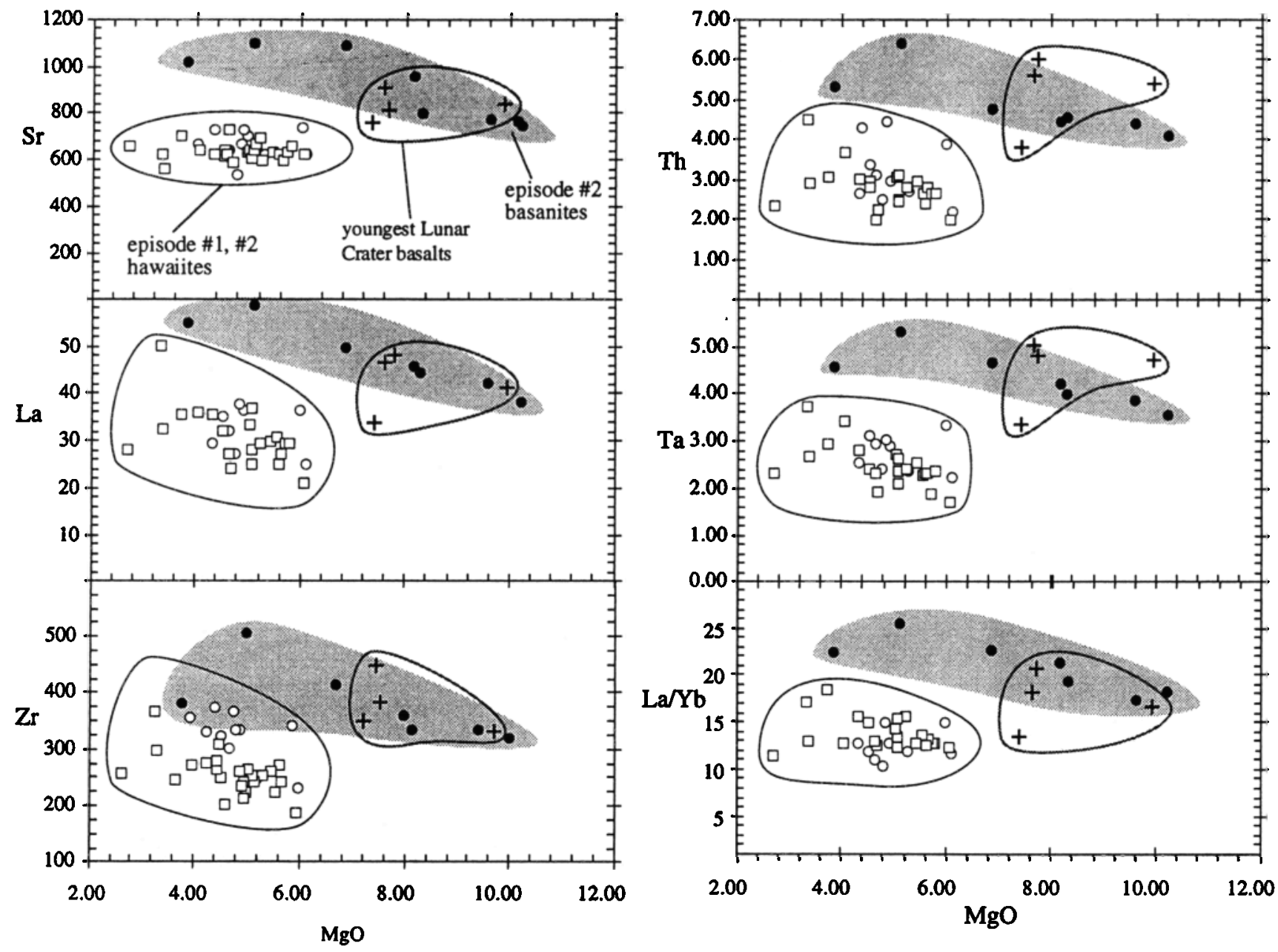

Figure 6. Incompatible elements ( $\mathrm{Sr}, \mathrm{La}, \mathrm{Zr}, \mathrm{Th}, \mathrm{Ta}, \mathrm{La} / \mathrm{Yb}$ ) versus $\mathrm{MgO}$ for alkalic basalts of the Reveille Range and for the youngest Lunar Crater Volcanic Field basalts (Qb-1 units from Bergman [1982]). Hawaiite samples from episode 1 (open squares) and episode 2 (open circles) generally have similar incompatible element concentrations relative to $\mathrm{MgO}$. Episode 2 basanites (solid circles) have relatively high concentrations of incompatible elements and high $\mathrm{La} / \mathrm{Yb}$ compared to MgO. Data from Table 2 and Bergman [1982].

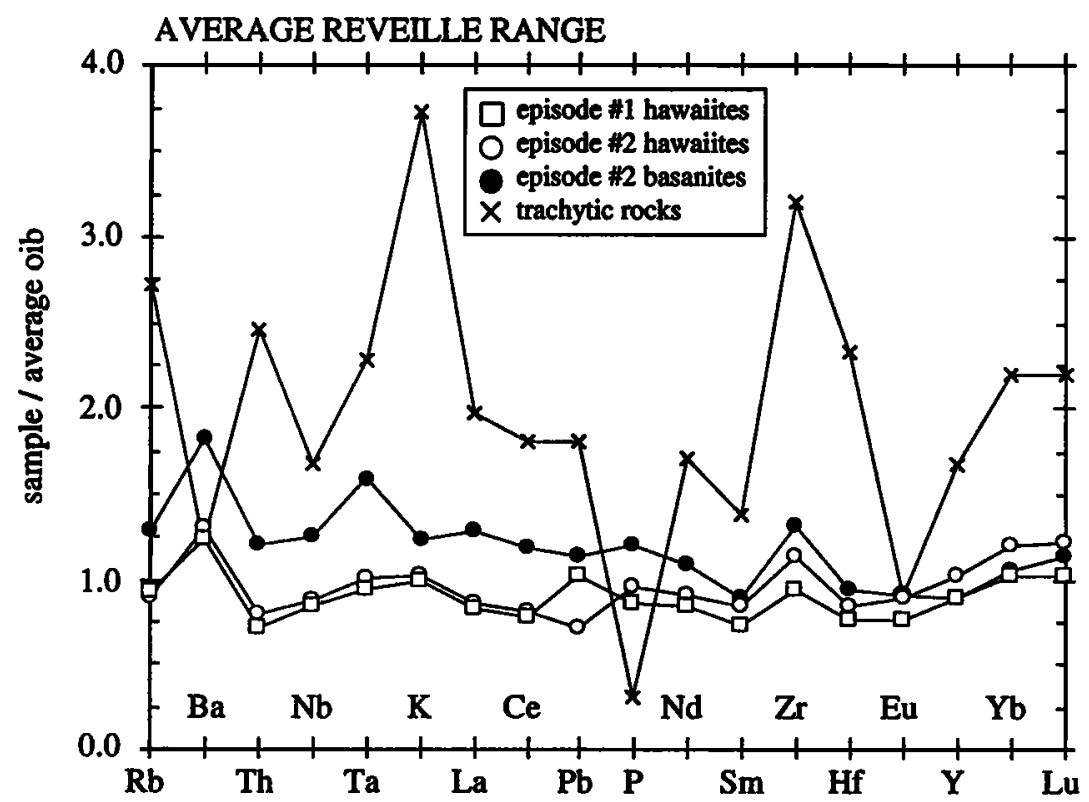

Figure 7. Average incompatible element concentrations for Reveille Range basalts normalized to average ocean island basalt of Sun and McDonough [1989]. Average episode 2 basanitic samples includes episode 2 basanites and episode 2 hawaiites with relatively high incompatible element concentrations (see Figure 6). Notice the similarity for ratios among most elements except $\mathrm{Pb}$ which is relatively high in only the episode 1 average (e.g., high $\mathrm{Pb} / \mathrm{Ce}$ in episode 1 hawaites). 


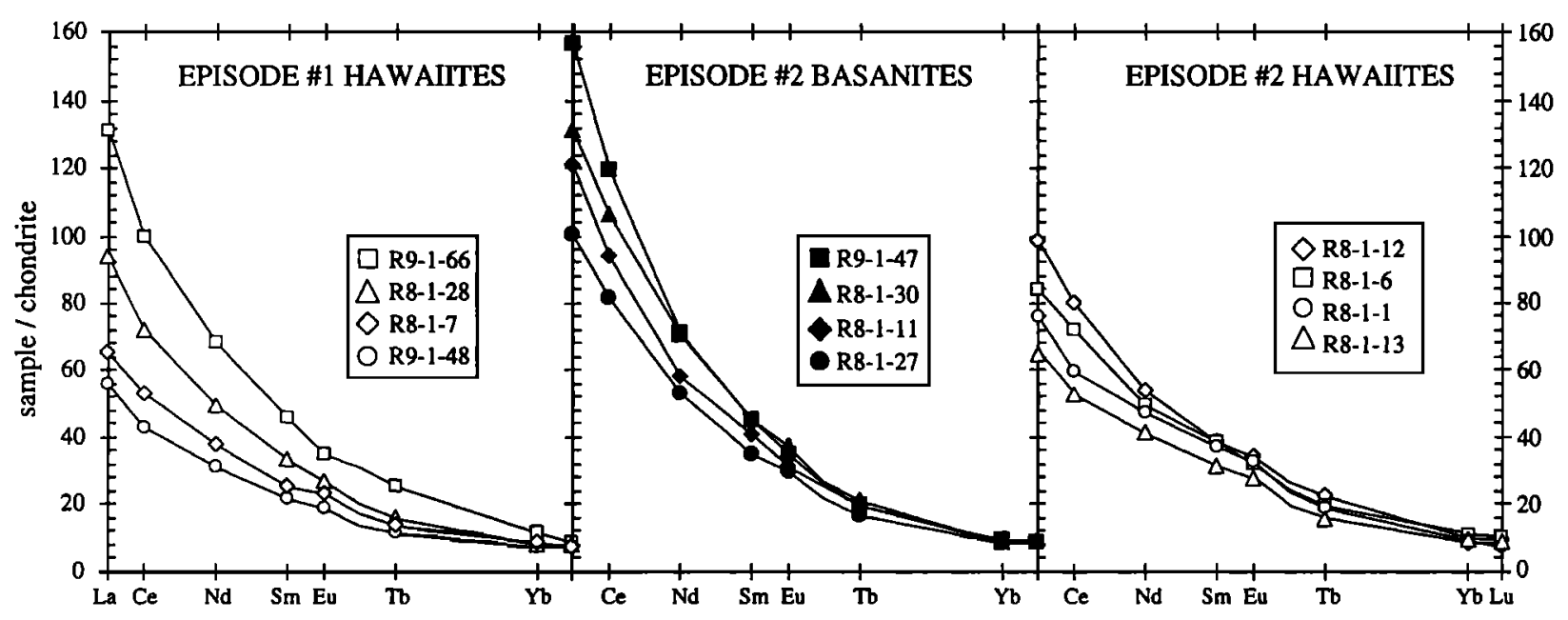

Figure 8. Chondrite-normalized rare earth element concentrations for Reveille Range basalts (Table 1). Samples plotted here were selected to show the full range of light rare earth element concentration within each stratigraphic-geochemical grouping (see also Figure 6). Normalizing values are the Leedy Chondrite: La (0.378), Ce (0.976), Nd (0.716), Sm (0.230), Eu (0.0866), Tb (0.0589), Yb (0.249), Lu (0.0387). See also Masuda et al. [1973].

Carbonates may have high concentrations of $\mathrm{Sr}$ but will generally have low concentrations of other incompatible elements. Carbonates also have high $\delta^{18} \mathrm{O}$ and $\mathrm{Sr} / \mathrm{Nd}$ and thereby have all of the features of the putative contaminant [cf. Veizer, 1983; Shaw, 1985].

The carbonate contaminant interpretation is supported by the observation that episode 1 samples with higher $\mathrm{Sr}$ concentrations also have higher ${ }^{87} \mathrm{Sr} / 86 \mathrm{Sr}$. Specifically, a plot of ${ }^{87} \mathrm{Sr} / 86 \mathrm{Sr}$ versus $\mathrm{Sr}$ concentration (Figure 13) shows that the episode 1 samples are scattered around a mixing line between an evolved basalt composition ( $\mathrm{Sr}=550 \mathrm{ppm},{ }^{87} \mathrm{Sr} / 86 \mathrm{Sr}=$ $0.7035)$ and a carbonate assimilant $\left(\mathrm{Sr}=850 \mathrm{ppm},{ }^{87} \mathrm{Sr} /\right.$ ${ }^{86} \mathrm{Sr}=0.7085$ ). The binary mixing line is equivalent to an assimilation-fractional crystallization (AFC) model wherein the bulk distribution coefficient for $\mathrm{Sr}$ is 1.0 (bulk $\mathrm{D}_{\mathrm{Sr}}=1.0$ [see DePaolo, 1981]). The data are somewhat scattered but are largely encompassed by AFC calculations using $\mathrm{D}_{\mathrm{Sr}}$ between 0.85 and 1.15 (Figure 13). There is no systematic change in $\mathrm{Sr}$ concentration over the range of $\mathrm{MgO}(2.7-6.1 \%)$ and $\mathrm{Al}_{2} \mathrm{O}_{3}$

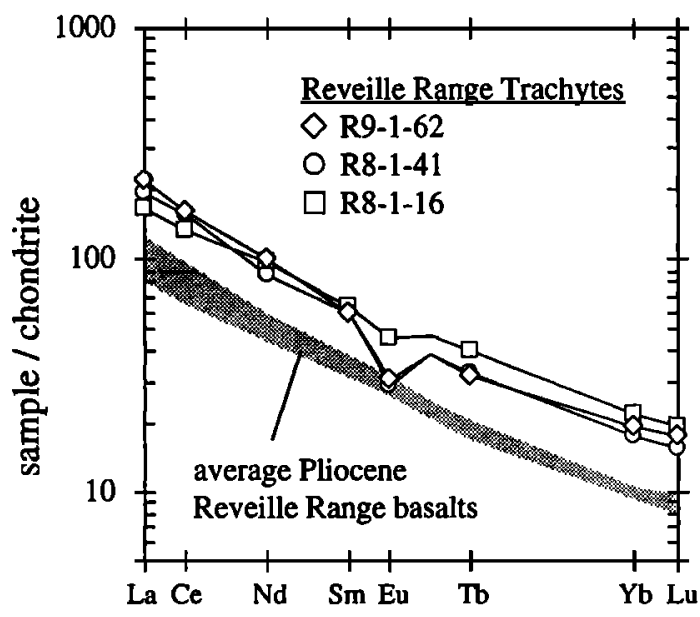

Figure 9. Chondrite-normalized rare earth element concentrations for Reveille Range trachytic rocks compared with basalts (data from Table 1).
(15.1-17.4\%) contents in episode 1 basalts, suggesting that $D_{S r}=1.0+/-0.15$ is appropriate.

Strontium isotopes in the episode 1 hawaiites also appear to be correlated with $\mathrm{SiO}_{2}$ content (Figure 14), and this may also reflect an $\mathrm{AFC}$ control over ${ }^{87} \mathrm{Sr} / 86 \mathrm{Sr}$. There are, however, no clear correlations between ${ }^{87} \mathrm{Sr} / 86 \mathrm{Sr}$ and other general indicators of crystal fractionation (e.g., decreasing $\mathrm{MgO}, \mathrm{CaO}$, $\mathrm{CaO} / \mathrm{Al}_{2} \mathrm{O}_{3}$, increasing $\mathrm{Ba}, \mathrm{Th}, \mathrm{K}$ ), but this may in part be because isotopic analyses are available for hawaiite samples that are all similarly evolved (MgO 4.5-6.1\%).

Mixing calculations indicate that the observed shift in ${ }^{87} \mathrm{Sr} / 86 \mathrm{Sr}$ (from 0.7035 to 0.7060 ) requires $10-40 \%$ assimilation of a carbonate that contains $850 \mathrm{ppm} \mathrm{Sr}$ with ${ }^{87} \mathrm{Sr} /{ }^{86} \mathrm{Sr}=0.7085$ and $\mathrm{Sr} / \mathrm{Nd}=85$ (Figure 12 ). This is a substantial amount of contamination, and it implies that radiogenic $\mathrm{Sr}$ mobilized in the wall rock reactions was efficiently incorporated into the basaltic melt. A large amount of $\mathrm{Sr}$ may have been liberated in wall rock reactions wherein $\mathrm{Ca}-\mathrm{Mg}$ carbonates (with variably high $\mathrm{Sr}$ ) are replaced by $\mathrm{Ca}-$ $\mathrm{Mg}$ silicates (with relatively low $\mathrm{Sr}$ ).

Minerals formed in a melt-carbonate reaction zone (e.g., wollastonite, garnet, Ti-Al-rich pyroxenes, nepheline) are not observed in the episode 1 basalts, nor do these basalts show shifts in major element composition that might be anticipated as a consequence of basalt-limestone interaction (e.g., Ca enrichment, Si-Al depletion [see Wyllie, 1974]). Detailed studies of basalt-limestone interaction indicate, however, that these petrologic consequences of limestone assimilation will be produced in only a very localized part of a magmatic system. Specifically, Baker and Black [1980] and Joesten [1977] found small veins and apophyses of strongly $\mathrm{Ca}$-rich hybridized basalt in melt-limestone reaction zones, but they concluded that these melts were produced in only very small volumes because elements liberated by carbonate breakdown (mostly Ca) were readily accommodated by crystallization within the reaction zone [see also Wyllie, 1974].

These studies of basalt-limestone interaction have reemphasized two important points initially made by Bowen $[1922,1928]$ in his classic treatment of wall rock assimilation. These are, first, that the sluggish transfer of heat from the 


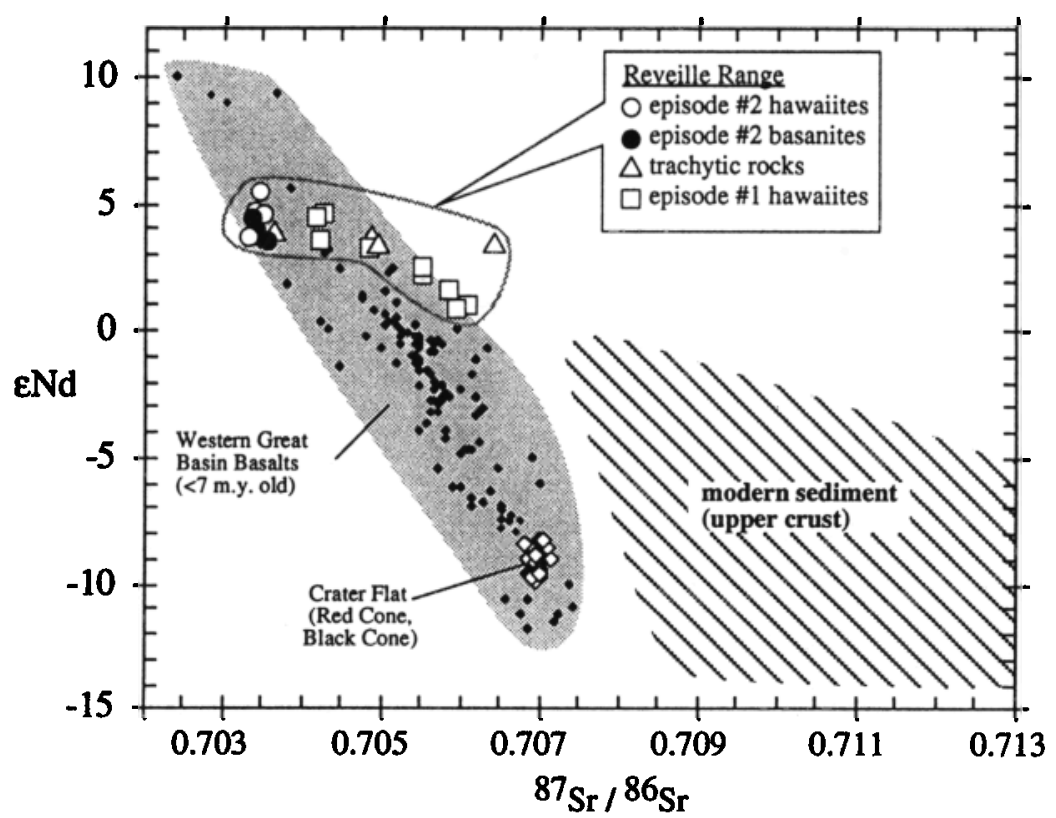

Figure 10. Nd -Sr isotope correlation diagram comparing Reveille Range data with basalts from throughout the southern Nevada area ( $<7$ m.y. old) and upper crust (as sampled by modern marine sediment). Notice the tight cluster of episode 2 data (hawaiites and basanites) and the "flat trend" of the episode 1 basalts toward high ${ }^{87} \mathrm{Sr} / 86 \mathrm{Sr}$ relative to $\varepsilon_{\mathrm{Nd}}$. Notice also that the Reveille Range trachytic rocks scatter to high relative ${ }^{87} \mathrm{Sr} /{ }^{86} \mathrm{Sr}$ values and in this way are isotopically akin to the episode 1 basalts. Reveille Range and Crater Flat data are from Table 2. Data for southern Nevada area basalts (< 7 m.y. old) are from Farmer et al. [1989], Coleman [1990], Walker and Coleman [1991], Feuerbach et al., [1993], Hoffine [1993], Ormerod [1988], and unpublished University of Nevada, Las Vegas, University of Kansas data. Modern marine sediment data are from Ben Othman et al. [1989].

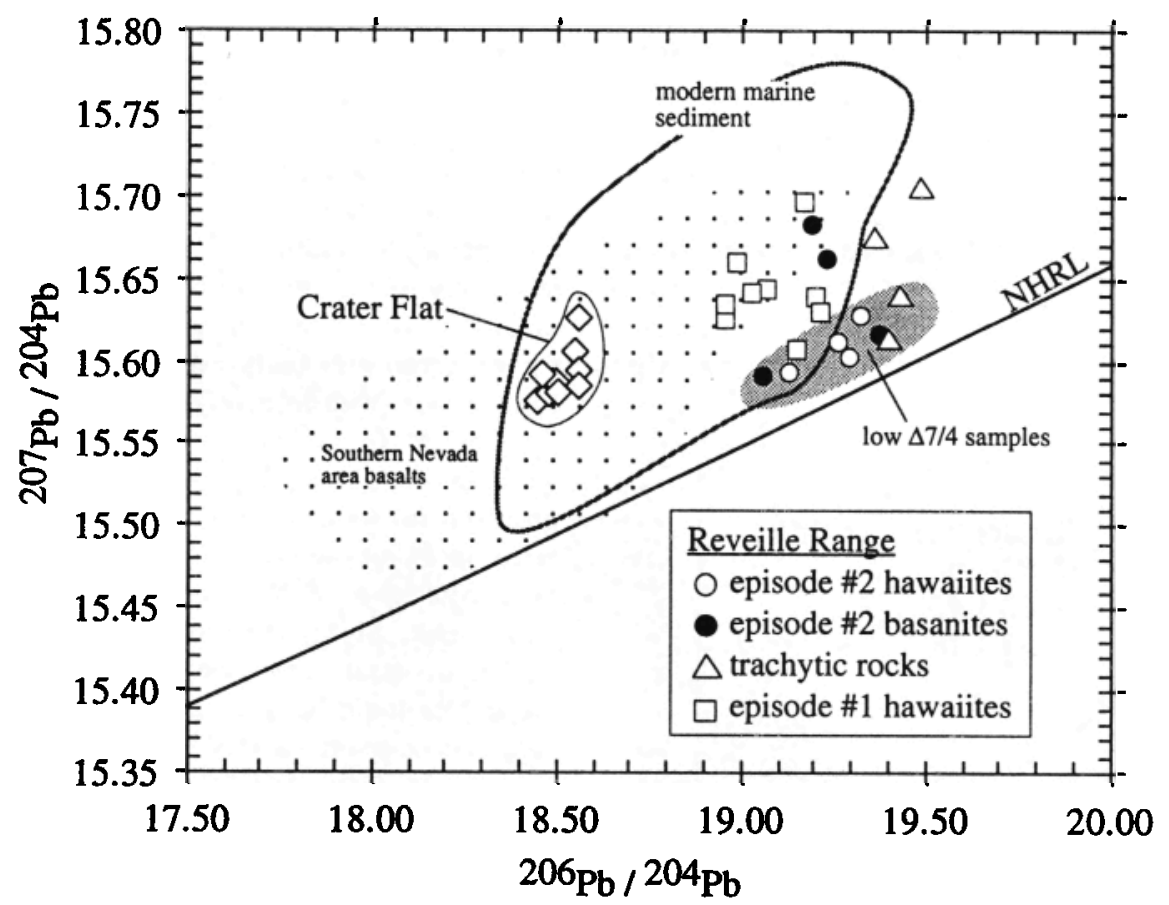

Figure 11. Lead isotope correlation diagram $(207 \mathrm{~Pb} / 204 \mathrm{~Pb}$ versus $206 \mathrm{~Pb} / 204 \mathrm{~Pb})$ comparing Reveille Range data to southern Nevada area basalts and modern marine sediment. Notice that six of eight episode 2 samples (including both hawaiites and basanites) fall along a trend parallel to the mantle reference line at low $\Delta 7 / 4 \mathrm{~Pb}$ [see Hart, 1984], whereas the episode 1 samples, including trachytic rocks, scatter to high relative ${ }^{207} \mathrm{~Pb} / 204 \mathrm{~Pb}$ (high $\Delta 7 / 4 \mathrm{~Pb}$ ). References for basalt data are the same as in Figure 10 . Lead isotope data for modern sediment from Ben Othman et al. [1989] and Kay et al. [1978], and references therein]. 


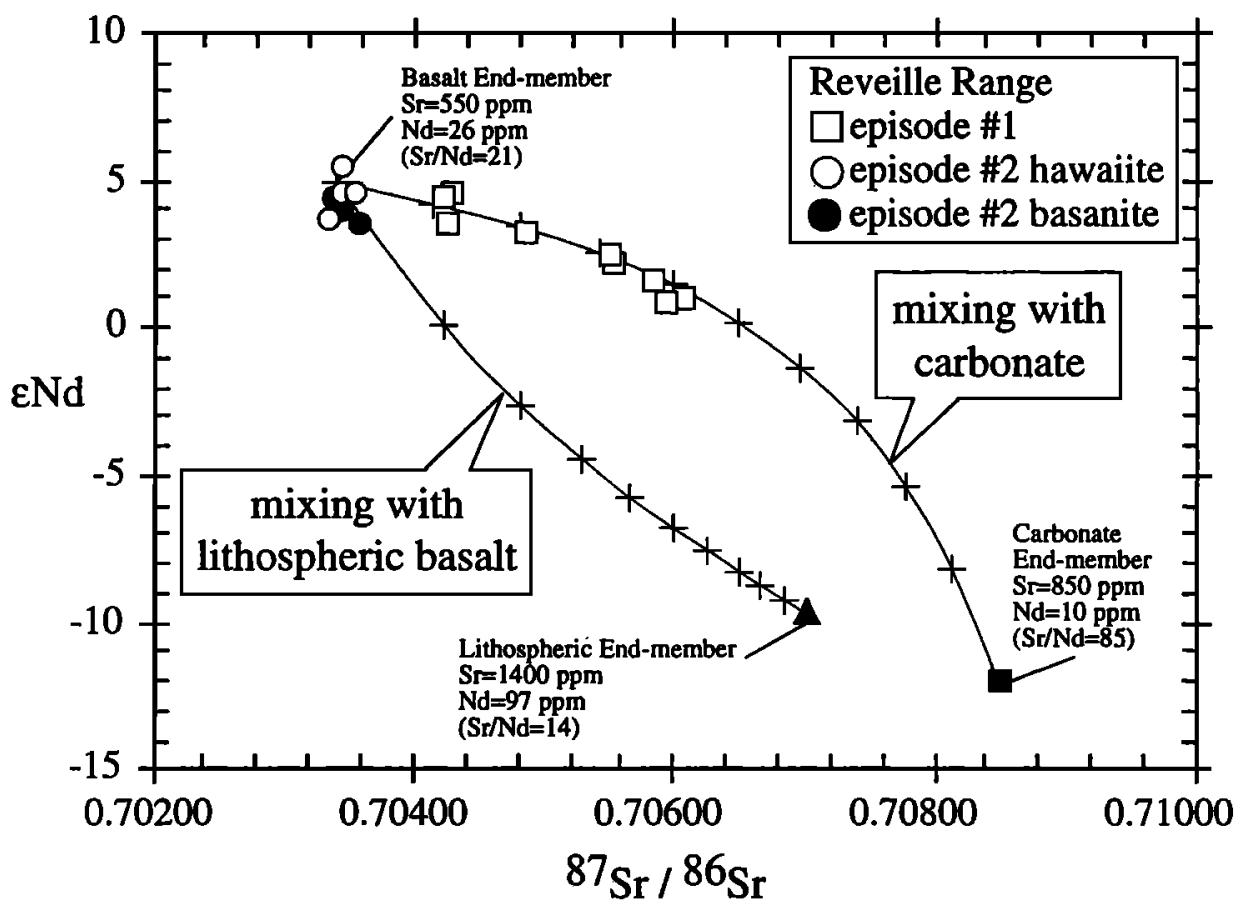

Figure 12. Neodymium-Sr isotope correlation diagram for Reveille Range basalts with binary mixing lines between low ${ }^{87} \mathrm{Sr} / 86 \mathrm{Sr}$ episode 2 basalts (hawaiites and basanites) and end-members with compositions of lithospheric basalt (high ${ }^{87} \mathrm{Sr} /{ }^{86} \mathrm{Sr}$, low $\mathrm{Sr} / \mathrm{Nd}$ ) and carbonate (high ${ }^{87} \mathrm{Sr} / 86 \mathrm{Sr}$, high $\mathrm{Sr} / \mathrm{Nd}$ ). Notice that the downward curvature of the carbonate mixing line and the trend toward high ${ }^{87} \mathrm{Sr} / 86 \mathrm{Sr}$ relative to $\varepsilon_{\mathrm{Nd}}$ match the episode 1 hawaiite trend well. Crosses on mixing lines are at increments of $10 \%$.

magma to the reaction zone means that energy for wall rock assimilation will generally come from crystallization within the reaction zone itself and, second, that elements mobilized by melt-wall rock reactions will generally be accommodated by solid solution in minerals crystallizing in the reaction zone.
In the case of limestone assimilation, this means that $\mathrm{Ca}$ liberated by carbonate breakdown will generally be crystallized as clinopyroxene within or near to the basalt-limestone reaction zone [Joesten, 1977; Baker and Black, 1980]. So basaltic lavas erupted from a magma system that interacted

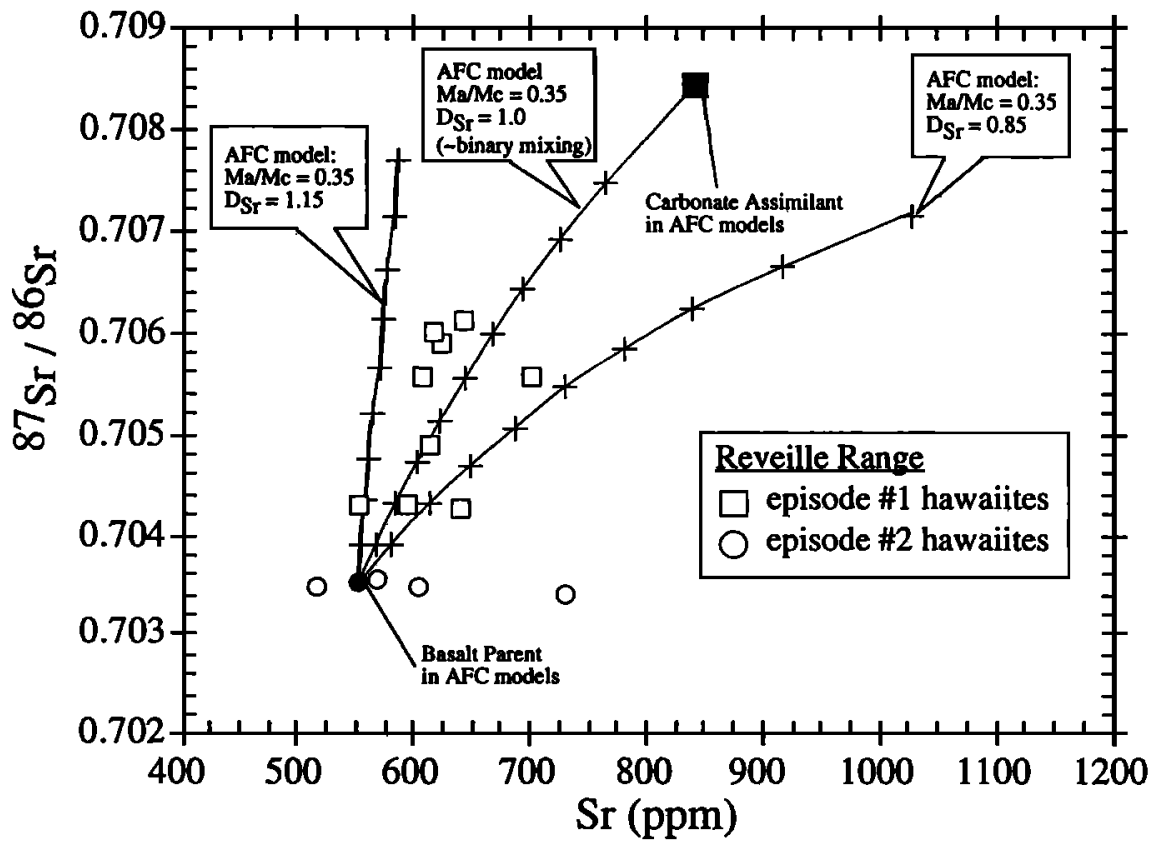

Figure 13. Sr isotopes versus $\mathrm{Sr}$ concentration and assimilation-fractional crystallization modeling (AFC [DePaolo, 1981]) of episode 1 basalts from the Reveille Range. Parameter " $r$ " in AFC calculations is the mass assimilated divided by the mass crystallized $(\mathrm{Ma} / \mathrm{Mc})$. Crosses on AFC curves are at increments of $10 \%$ crystallization. 


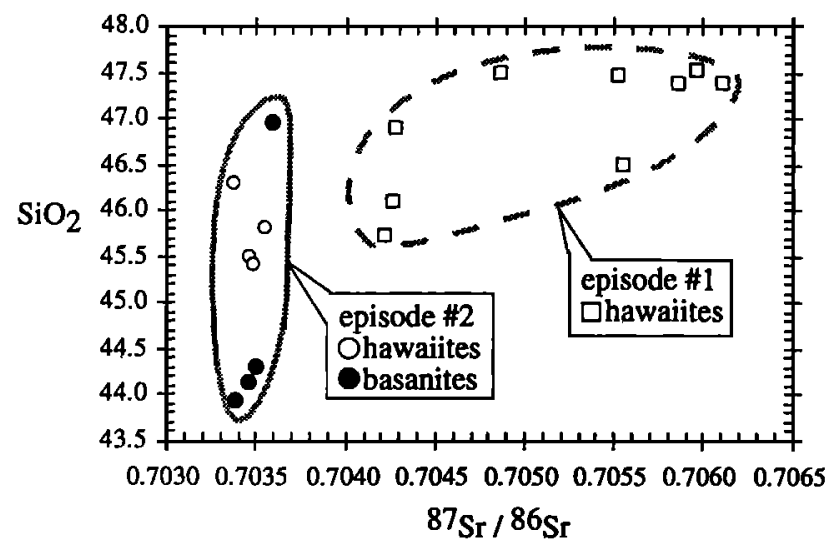

Figure 14. $\mathrm{Sr}$ isotopes versus $\mathrm{SiO}_{2}$ content for Reveille Range basalts. Note the general increase in ${ }^{87} \mathrm{Sr} / 86 \mathrm{Sr}$ with increasing $\mathrm{SiO}_{2}$ among Reveille Range hawaiites. Data from Tables 2 and 4.

extensively with limestone are generally not expected to show anomalous behavior in $\mathrm{CaO}$ or other major elements.

For our purposes it is perhaps most interesting that the strongly hybridized basalts analyzed by Baker and Black [1980] were enriched in $\mathrm{CaO}$ by approximately a factor of 2.4 (over the unhybridized basalts), but were enriched in $\mathrm{Sr}$ by up to a factor of 15 [see Baker and Black, 1980, Table II]. This profound enrichment in $\mathrm{Sr}$ over $\mathrm{CaO}$ in the small-volume hybridized melts provides clear and tangible evidence that $\mathrm{S}$ liberated in carbonate breakdown is preferentially excluded from the Ca-silicate minerals that crystallize in a basaltlimestone reaction zone. We conclude that in the case of the episode 1 hawaiites in the Reveille Range such displaced $\mathrm{Sr}$ may have been efficiently incorporated into the basaltic melts.

Assuming that significant $\mathrm{Sr}$ may be liberated by meltlimestone interaction, we turn to the question of how that $\mathrm{Sr}$ was incorporated into the episode 1 hawaiite magmas. Much of the radiogenic $\mathrm{Sr}$ diffusing away from the wall rock reaction zone may have been scavenged by feldspars crystallizing in the cumulate mush. Pieces of this mush zone in the form of megacrystic and large phenocrystic plagioclase are common in the episode 1 basalts. Aluminum-87 $\mathrm{Sr} / 86 \mathrm{Sr}$ mixing relationships indicate, however, that mechanical incorporation of feldspar from the mush zone cannot account for the shift in $\mathrm{Sr}$ isotope compositions observed in the episode 1 samples (Figure 15).

If radiogenic $\mathrm{Sr}$ was not carried into the basaltic melt by plagioclase crystals, then it must have been transferred from the reaction zone to the melt largely by diffusion. Other elements that may move efficiently by diffusion do not appear, however, to have been as strongly affected as does Sr. There are no clear relationships between $\mathrm{Ba}$ or $\mathrm{Ba} / \mathrm{La}$ and ${ }^{87} \mathrm{Sr} / 86 \mathrm{Sr}$, and correlations between $\mathrm{K}$ or $\mathrm{K} / \mathrm{La}$ and ${ }^{87} \mathrm{Sr} /{ }^{86} \mathrm{Sr}$ are weak despite the fact that the diffusive mobility of $K$ is thought to be relatively high in systems where basalt is assimilating crustal rocks [Watson, 1982; Watson and Jurewicz, 1983]. The $\mathrm{Pb}$ data do show a trend toward higher $\mathrm{Pb} / \mathrm{La}$ with increasing ${ }^{87} \mathrm{Sr} / 86 \mathrm{Sr}$, but one sample nonetheless has very radiogenic $\mathrm{Sr}$ and also low relative $\mathrm{Pb}$ (Figure 16). We conclude therefore that the episode 1 hawaiites were altered by assimilation of a wall rock that had high concentrations of $\mathrm{Sr}$ (and possibly $\mathrm{Pb}$ )

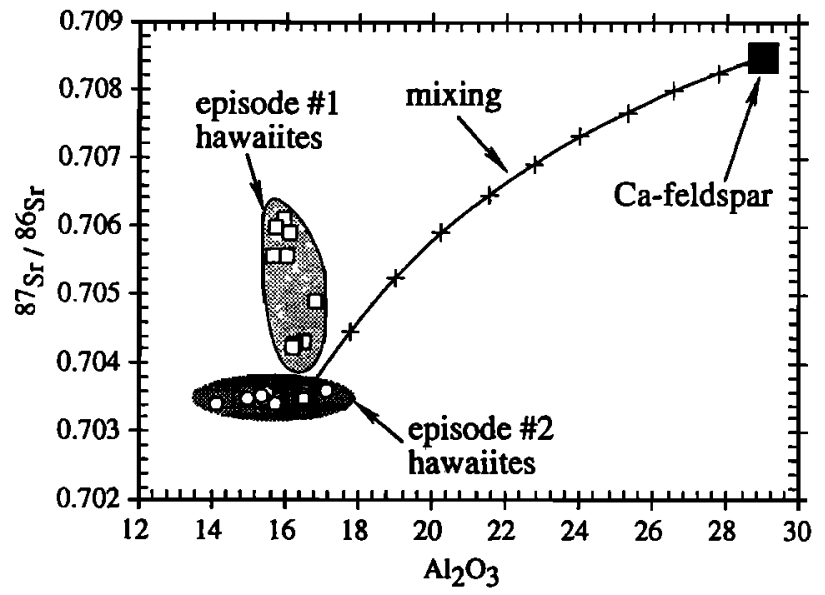

Figure 15. Strontium isotopes versus $\mathrm{Al}_{2} \mathrm{O}_{3}$ content for Reveille Range basalts compared with hypothetical $\mathrm{Ca}$ feldspar with high ${ }^{87} \mathrm{Sr} /{ }^{86} \mathrm{Sr}$. The trend of the mixing line fails to pass through the episode 1 data indicating that mechanical incorporation of Ca-feldspar (i.e., plagioclase megacrysts) with high $87 \mathrm{Sr} / 86 \mathrm{Sr}$ cannot explain the $\mathrm{Sr}$ isotopic composition of the episode 1 samples. Strontium concentration in feldspar used in mixing calculations is 1200 ppm and is similar to the $\mathrm{Sr}$ concentration in a labradorite megacryst analyzed by Bergman [1982]. Only unreasonably high Sr concentrations for plagioclase $(>10,000 \mathrm{ppm})$ will bend the mixing line to pass through the episode 1 data.

compared to other incompatible elements (i.e., a carbonaterich wall rock).

\section{Other Geologic and Petrographic Support \\ for the Carbonate Assimilation Model}

The olivine + plagioclase phenocryst assemblage in the episode 1 basalts contrasts with the higher pressure phenocryst-megacryst-xenolith assemblage present in younger basalts in the area (see petrographic descriptions above). The phenocryst assemblage in episode 1 hawaiites is therefore consistent with evolution in a low-pressure magma chamber in the upper crust. The explosive eruption of the highly evolved trachytic rocks isotopically akin to the episode 1 hawaiites $\left({ }^{87} \mathrm{Sr} /{ }^{86} \mathrm{Sr}>0.7040\right)$ probably marked the cooling and death of that high level magma system.

We know therefore that among Pliocene-Pleistocene basalts in the area, the episode 1 hawaiites were erupted in the largest volume (see geologic map in Figure 2), they resided in the shallowest magma chamber (plagioclase-olivine-dominated phenocryst assemblage, see Table 1), and they eventually cooled to produce the most evolved melts (the trachytic rocks). All of these features are consistent with the model that the episode 1 hawaiites appear to have experienced contamination in the upper crust whereas younger basalts in the area (i.e., episode 2 and Lunar Crater) do not.

Petrographic support of the assimilation model is also present. Small phenocrysts of biotite appear in some episode 1 hawaiites but not in basalts of episode 2 (Table 1). Biotite is also well-developed groundmass phase in the episode 1 basalts but is much less common in basalts of episode 2. The presence of groundmass calcite in the Reveille basalts may also be significant. We have interpreted calcite in episode 1 basalts 


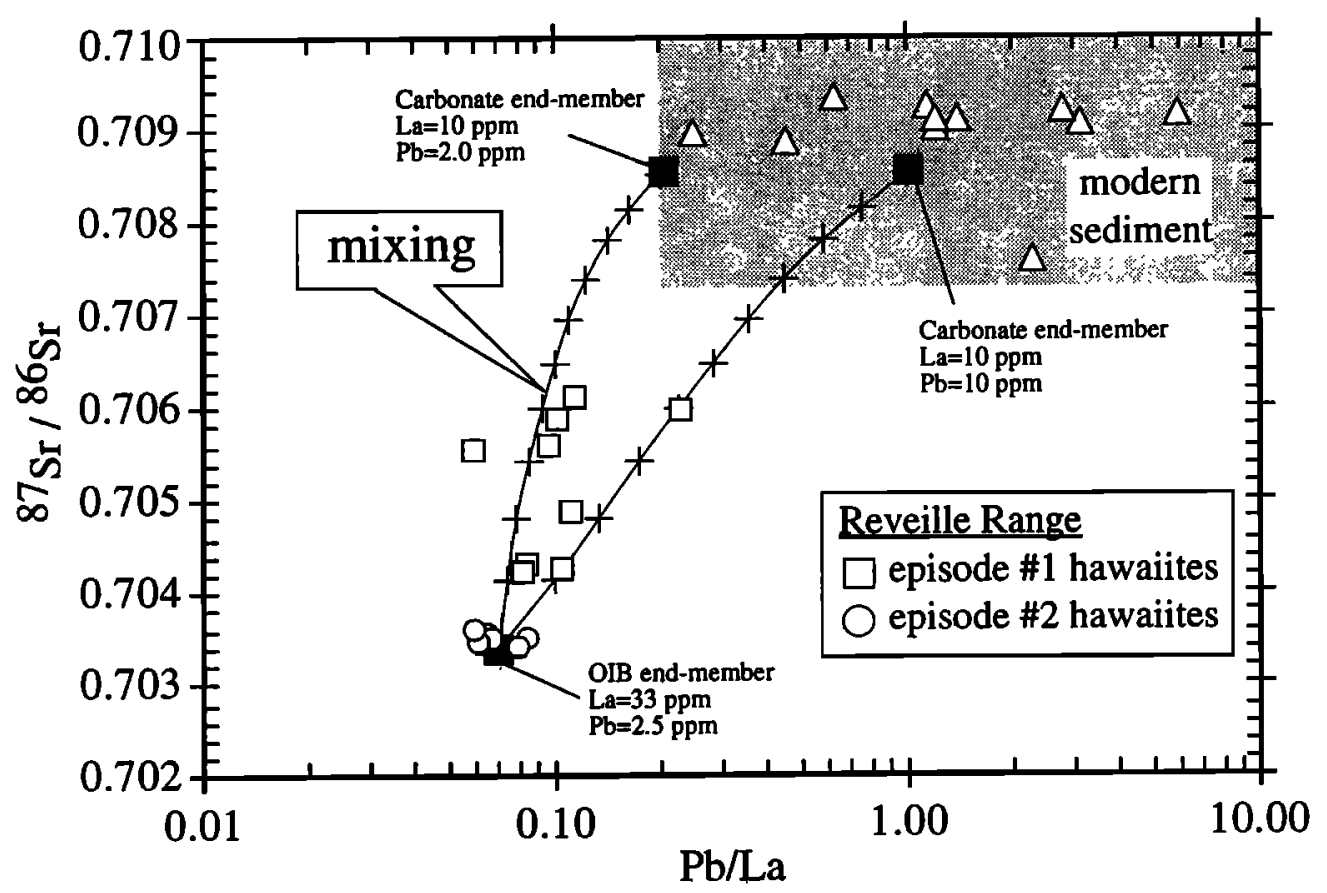

Figure 16. Strontium isotopes versus $\mathrm{Pb} / \mathrm{La}$ for Reveille Range rocks with mixing lines between upper crust compositions and episode 2 basalts. Notice the trend for most of the episode 1 data toward increasing $\mathrm{Pb} / \mathrm{La}$ with increasing ${ }^{87} \mathrm{Sr} / 86 \mathrm{Sr}$. Reveille Range data are from Table 2 and Ben Othman et al. [1989].

as largely alteration-related (see petrographic descriptions above), but in some cases, groundmass calcite is intergrown along straight crystal boundaries with biotite and feldspar in areas where there is no hint of alteration (aside from the presence of calcite). The textures suggest that some of the groundmass carbonate could magmatic or deuteric, though on this point the textural evidence is probably not conclusive.

Perhaps most importantly, quartzo-feldspathic xenoliths and xenocrysts are not seen in the Reveille Range episode 1 hawaiites, even in the presence of clear geochemical evidence for crustal contamination. In this regard, the Reveille Range basalts are unlike the Pliocene Colville Mesa basalts of the Lake Mead Area and certain Miocene age hawaiites in the Basin and Range of Mexico [Feuerbach et al., 1993; Luhr et al., 1995]. In these areas, geochemical evidence for crustal assimilation is supported by abundant petrographic evidence in the form of gneissic xenoliths and quartz xenocrysts, presumably from the deep crust.

Finally, it is important to recognize that Paleozoic and late Precambrian carbonates constitute a great thickness of the uppermost crust beneath central Nevada (6-12 km [Langenheim and Larson, 1972]) and that they are therefore the most probable source of upper crustal contamination in young basalts in the area. Most of the limestone section has probably undergone diagenesis and may not therefore have particularly high $\mathrm{Sr}$ concentrations (aragonite is $\mathrm{Sr}$-rich, calcite and dolomite are not), but the great thickness of miogeoclinal carbonate in south-central Nevada at least raises the possibility for the preservation or formation of $\mathrm{Sr}$-rich carbonate horizons beneath the Reveille Range.

We conclude that available geologic and petrographic data provide broad support to the idea, developed on the basis of geochemistry, that the episode 1 basalts in the Reveille Range experienced significant contamination in the upper crust, and that younger basalts in the area (episode 2 and Lunar Crater basalts) generally did not [see also Foland and Bergman, 1992].

\section{Discussion}

\section{Alternatives to the Carbonate Assimilation Model}

The geochemical variation in the episode 1 lavas constrains fairly tightly the nature of the high ${ }^{87} \mathrm{Sr} / 86 \mathrm{Sr}$ component in these rocks and would appear to eliminate the mantle as a potential source for this signature. The EMII enriched mantle component, which is widespread in OIB of certain western Pacific Islands [Zindler and Hart, 1986], produces a Nd-Sr array that falls directly over the episode 1 data. However, the absence of this isotopic signature from episode 2 and Lunar Crater basalts (which have incompatible element characteristics like those of episode 1) argues that the radiogenic Sr did not come from the asthenospheric source. Enriched lithospheric mantle beneath the western United States generally has low $\mathrm{Sr} / \mathrm{Nd}$ and $\mathrm{Sr}-\mathrm{Nd}$ isotope ratios that produce a steep negative trend on the $\mathrm{Nd}-\mathrm{Sr}$ isotope correlation diagram (e.g., Crater Flat data in Figure 10) which is unlike the trend produced by the episode 1 data. In addition, the high ${ }^{87} \mathrm{Sr} / 86 \mathrm{Sr}$ basalts of episode 1 show no signs of having acquired the distinctive trace element characteristics of Great Basin lithospheric mantle (see Figures 4 and 5).

Assimilation of plagioclase-rich rocks in the deep crust may be another alternative to the carbonate assimilation model outlined above. Geochemically, an anorthosite would have the characteristics required of the assimilant (high ${ }^{87} \mathrm{Sr} / 86 \mathrm{Sr}$, $\mathrm{Sr} / \mathrm{Nd}, \delta^{180}$, low concentrations of other incompatible 
elements), but with no a priori evidence for an anorthosite body beneath central Nevada, this can only be an ad hoc interpretation. Glazner et al. [1991] and Glazner and Farmer [1992] argue that extensive assimilation of gabbroic rocks in the deep crust may account for diverse isotopic characteristics in basalts from the Mojave area of southeastern California. Indeed, some Mojave basalts follow a Sr-Nd isotopic trend similar to that seen in episode 1 hawaiites from the Reveille Range. There is, however, no clear relationship between Sr-Nd isotopes and $\delta^{18} \mathrm{O}$ in the Mojave basalts [Glazner et al., 1991, Figure 10] and in this way they contrast the Reveille RangeLunar Crater rocks [Foland et al., 1991; Foland and Bergman, 1992]. Furthermore, the unusual element-isotope correlations seen in the Mojave basalts [Glazner et al., 1991, Figure 12] are absent from the episode 1 hawaiites. We conclude therefore that the assimilation process that has operated in the genesis of the Mojave basalts is unlike that which has effected the episode 1 hawaiites in the Reveille Range.

Postmagmatic alteration might also explain radiogenic $\mathrm{Sr}$ and high $\delta^{18} \mathrm{O}$ in the episode 1 basalts. One possibility is that meteoric waters have carried dissolved carbonate dust into cracks and other openings in the episode 1 basalts (samples were not leached in acid prior to isotopic analysis). Episode 1 basalts are slightly older, so pedogenic processes would have had more time to operate on them than on the younger episode 2 rocks. Recall, however, that all of the Reveille Range basalts are Pliocene in age, so if pedogenic processes have affected basalt compositions, it is surprising that the alteration affects are so clearly present in the episode 1 rocks (4.5-6 m.y. old) but are completely absent from the episode 2 rocks (3-4.5 m.y. old). A second possibility is that alteration in the episode 1 samples was produced by a hydrothermal system established following the eruption of the episode 1 basalts and trachytic rocks. If a hydrothermal system were not established following the eruption of the relatively small volume episode 2 basalts, then those basalts would have escaped alteration.

The problem though, with any hydrospheric interpretation for the origin of the crustal component in episode 1 basalts, is that it requires that all of the contaminant $\mathrm{Sr}$ and $\mathrm{Nd}$ be carried in the relatively small amount of (apparently alterationrelated) calcite that is present in the rocks. The large amount of contaminant $\mathrm{Sr}$ and $\mathrm{Nd}$ required by mass balance (10-40\%, see Figure 12), and the small amount of calcite present (less than $\sim 3 \%$ ) therefore argue strongly against a hydrospheric origin for the observed isotopic shifts. In general, we believe that a magmatic origin is far more likely to mobilize the large amount of $\mathrm{Sr}$ and $\mathrm{Nd}$ required to explain the observed isotopic variation.

\section{Implications for the Evolution of the Volcanic Field}

Geologic, petrographic, and geochemical evidence outlined above indicates that between 5 and $6 \mathrm{~m} . y$. ago, episode 1 hawaiites in the Reveille Range were contaminated by wall rock assimilation in an upper crustal magmatic plumbing system. This high level magma system is interpreted to have cooled and died $4.5 \mathrm{~m}$.y. ago with the explosive eruption of trachytic lavas and pyroclastic surges in the northeastern Reveille Range. The evidence therefore indicates that the episode 1 hawaiites and the trachytic rocks were part of a single eruptive episode and that this episode was $1.0-1.5 \mathrm{Myr}$ in duration.

Because the episode 2 basalts immediately overlie but are isotopically distinct from the trachytic rocks and the basalts of episode 1 , we believe that the episode 2 basalts represent the beginning of a new exuptive episode for the volcanic field. It is unlikely that episode 2 basalts could have reoccupied the shallow episode 1 storage system without also showing isotopic evidence of crustal contamination, so we conclude that episode 2 eruptions were fed from a separate storage location. The widespread occurrence of clinopyroxene phenocrysts and megacrysts in episode 2 basalts indicates that this storage location was deeper than during episode 1 time. This is confirmed, at least in part, by the presence of mantlederived xenoliths (dunites, harzburgites) and amphibole megacrysts in some of the episode 2 basanites. These xenoliths provide good evidence that their host basalts were stored near the crust-mantle boundary and were erupted rapidly without a significant period of storage within the shallow crust.

The presence of basanites among only the episode 2 rocks may provide further insight into the development of the volcanic field. Specifically, the episode 2 basanites are more alkaline ( $>5 \%$ normative nepheline) than the hawaiites, indicating a greater depth of melting (higher pressure melts [O'Hara, 1968; see also Takahashi and Kushiro, 1983; Klein and Langmuir, 1987]). The basanites also have higher incompatible element concentrations than the hawaiites (relative to $\mathrm{MgO}$, Figure 6), and assuming that the mantle source of Reveille Range hawaiites and basanites was compositionally similar (an assumption that is strongly supported by the isotopic data presented here), these higher incompatible element concentrations imply a lower percentage melting for the basanites. Other compositional features of the basanites, including steeper REE patterns (higher $\mathrm{La} / \mathrm{Yb}$, Figure 6) and higher $\mathrm{Na}_{8.0}$ (Table 2), also point to a low percentage melting origin for the basanites compared to the hawaiites. The overall low volume of basanite in the Reveille Range argues further that these basalts were produced by smaller percentage melting than the associated hawaiites which were produced in relatively large volumes, especially during episode 1 time.

The secular trend toward deeper and lower volume melting can be extended into the Pleistocene with the formation of the youngest basalts in the Lunar Crater Volcanic field (Qb-3 units from the Lunar Crater Volcanic Field [see Scott and Trask, 1971]). These basalts occur in very small volumes, they are more strongly alkaline (9-14\% normative nepheline) than the Reveille Range basanites, they have high $\mathrm{MgO}$ and high incompatible element contents (Figure 6), and they have relatively steep REE patterns (high $\mathrm{La} / \mathrm{Yb}$, Figure 6). The youngest Lunar Crater basalts also contain an abundant and diverse suite of both type I and type II megacrysts and nodules [Bergman, 1982]. These data clearly require that the youngest Lunar Crater basalts were formed by low percentage melting of a relatively deep mantle source and that they traveled from the mantle to the surface at relatively high velocities.

Comparison of the Reveille Range data with the mapping of Scott and Trask [1971] in the Pancake Range suggests that through time, there have been systematic shifts in the geographical shift distribution of eruptions across the region. In its early history (3-6 Myr ago), the volcanic field covered a 


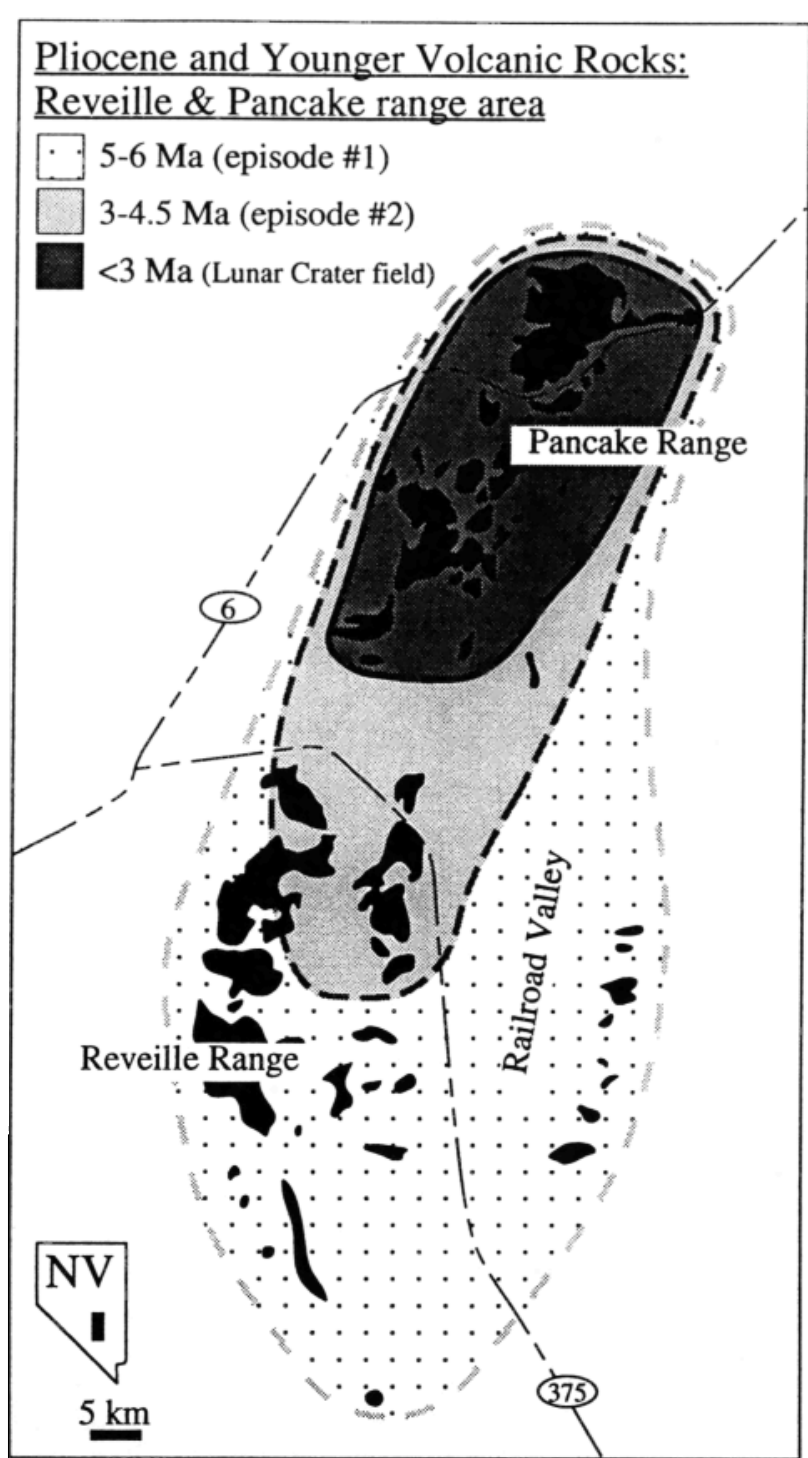

Figure 17. Time-space patterns for volcanism in the Reveille and Pancake ranges from approximately $6 \mathrm{Ma}$ to present. Based on mapping presented here (Figure 2) and from Scott and Trask [1971].

broad area that encompassed what are today the Reveille and Pancake ranges. By the end of the Pliocene and in Pleistocene time, the area over which basalts were erupting had retreated to a small area in the north which today is marked by the distribution of the youthful cones of the Lunar Crater Volcanic field (Figure 17). It appears that the initial melting anomaly that produced the volcanic field was large and that subsequent melting episodes were smaller and centered at the northern end of the initially large outbreak. These general time-space trends were also noted by Naumann et al. [1991] and Foland and Bergman [1992].

Available age information indicates that in the Reveille Range the volcanic field developed in at least two eruptive episodes which were apparently both 1.0-1.5 Myr long. The presence of both hawaiite and basanite within the episode 2 sequence, and the relatively young age for the only basanite sample that has been dated (3.0 Ma [see Naumann et al., 1991]), suggests that episode 2 may itself be two separate eruptive episodes (first the hawaiites, then the basanites). The duration of the episode 2 episode is, however, poorly constrained because there are relatively few radiometric ages and because many of the 3-4.5 Myr old basalts are located in the Pancake Range where the Pliocene stratigraphy is less well established. It may be that the lengths of the eruptive episodes have changed with time, such that as the volcanic field aged, eruptive episodes that produced the younger and smaller volume basalts were shorter than those that produced older, larger volume episodes. Only a more detailed knowledge of the Pliocene stratigraphy in the Pancake Range will allow us to address this aspect of the volcanic field history.

Overall, the volcanic field appears to have developed in response to spatially and temporally discrete melting events in the mantle. The possible role of lithospheric extension or delamination in triggering these melting events cannot, however, be evaluated without a substantial knowledge of local and regional structural/tectonic events at a resolution of approximately 1-2 Myr. The idea that the formation of small volume mafic volcanic fields may be coupled to specific tectonic events therefore appears to be beyond our current understanding of tectonic events for most parts of the Basin and Range.

Acknowledgments. Helpful reviews by Todd Housh, Britt Hill, and Associate Editor William Melson are gratefully acknowledged. This manuscript also benefited from discussions with Richard Carlson and Erik Christianson. A helpful review of an early version of this manuscript was provided by Terry Plank. Thanks also to Shirley Morikawa and Alex Sanchez for their assistance in the laboratory aspects of this study. Pat Braught provided valuable assistance in preparing camera-ready copy. This research was supported by the Nevada Nuclear Waste Projects Office. We thank Carl Johnson of that office for his support.

\section{References}

Baker, C.K., and P.M. Black, Assimilation and metamorphism at a basaltlimestone contact, Tokatoka, New Zealand, Mineral. Mag., 43, 797$807,1980$.

Ben Othman, D., W.M. White, and J. Patchett, The geochemistry of marine sediments, island arc magma genesis, and crust-mantle recycling, Earth Planet. Sci. Lett., 94, 1-21, 1989.

Bergman, S.C., Petrogenetic aspects of the alkali basaltic lavas and included megacrysts and nodules from the Lunar Crater Volcanic Field, Nevada, U.S.A., Ph.D. thesis, 431 pp., Princeton Univ., Princeton, N.J., 1982.

Bowen, N.L., The behaviour of inclusions in igneous magmas, J. Geol. , 30, 513-570, 1922.

Bowen, N.L., The Evolution of Igneous Rocks, 332 pp., Princeton Un iv. Press, Princeton, N.J., 1928.

Bradshaw, T.K., and E.I. Smith, Polygenetic Quatemary volcanism at Crater Flat, Nevada, J. Volcanol. Geotherm. Res., 63, 165-182, 1994.

Bradshaw, T.K., C.J. Hawkesworth, and K. Gallagher, Basaltic volcanism in the southern Basin and Range: no role for a mantle plume, Earth Planet. Sci. Lett., I16, 45-62, 1993.

Coleman, D.S., and J.D. Walker, Geochemistry of Mio-Pliocene volcanic rocks from around Panamint Valley, Death Valley a re a Califomia, in Basin and Range Extensional Tectonics Near the Latitude of Las Vegas, Nevada, edited by B. Wernicke, Mem. Geol. Soc. Am., 176, 391-411, 1990.

DePaolo, D.J., Trace element and isotopic effects of combined wallrock assimilation and fractional crystallization, Earth Plant. Sci. Lett., 53, 189-202, 1981.

Eaton, G.P., R.R. Wahl, H.J. Prostka, and M.D. Kleinkopf, Regional gravity and tectonic patterns: their relation to late Cenozoic epeirogeny and lateral spreading in the western Cordillera, in Cenozoic Tectonics and Regional Geophysics of the Western Cordillera, edited by R. B. Smith and G. P. Eaton, Mem. Geol. Soc. Am. , 152, pp. 51-92, 1978. 
Farmer, G.L., F.V. Perry, S. Semken, B. Crowe, D. Curtis, and D . J DePaolo, Isotopic evidence on the structure and origin of subcontinental lithospheric mantle in southern Nevada, $J$. Geophys. Res., 94, 7885-7898, 1989.

Feuerbach, D.L., E.I. Smith, J.D. Walker, and J.A. Tangeman, The role of the mantle during crustal extension: Constraints from geochemistry of volcanic rocks in the Lake Mead area, Nevada and Arizona, Geol. Soc. Am. Bull., 105, 1561-1575, 1993.

Fitton, J.G., D. James, P.D. Kempton, D.S. Ormerod, and W.P. Leeman, The role of lithospheric mantle in the generation of late Cenozoic basic magmas in the western United States, $J$. Petrol., Special Lithosphere Issue, 331-349, 1988.

Fitton, J.G., D. James, and W.P. Leeman, Basic magmatism associated with Late Cenozoic extension in the western United States: Compositional variations in space and time, J. Geophys. Res., 96, 13,693-13,711, 1991.

Foland, K.A., and S.C. Bergman, Temporal and spatial distribution of basaltic volcanism in the Pancake and Reveille ranges north of Yucca Mountain, paper presented at Third International Conference on High Level Radioactive Waste Management, American Nuclear Society, LaGrange Park, Ill., 2366-2371, 1992.

Foland, K.A., S.C. Bergman, A.W. Hofmann, and I. Raczek, Nd and Sr isotopic variations in alkali basalts and megacrysts from the Lunar Crater Volcanic Field, Nevada, EOS Trans. AGU, 64, 338, 1983.

Foland, K.A., J.S. Kargel, C.L. Lum, and S.C. Bergman, Timespatial-composition relationships among alkali basalts in the vicinity of the Lunar Crater, south-central Nevada, Geol. Soc Am. Abstr. Programs, 19, 666, 1987.

Foland, K.A., D.E. Schucker, B.M. Smith, W. Todt, and S.C. Bergman, Isotope geochemistry of Cenozoic alkali basalts in the vicinity of the Lunar Crater volcanic field, south-central Nevada: $\mathrm{O}$ and $\mathrm{Pb}$ evidence for crustal components, Geol. Soc. $A \mathrm{~m}$. Abstr. Programs, 23, 45, 1991.

Glazner, A.F., and G.L. Farmer, Production of isotopic variability in continental basalts by cryptic crustal contamination, Science, 255, 7274, 1992.

Glazner, A.F., G.L. Farmer, W.T. Hughes, J.L. Wooden, and W. Pickthom, Contamination of basaltic magma by mafic crust at Amboy and Pisgah craters, Mojave Desert, California, $J$. Geophys. Res., 96, 13,673-13,691, 1991.

Hart, S.R., A large-scale isotope anomaly in the southem hemisphere mantle, Nature, 309, 753-757, 1984.

Hedge, C.E., and D.C. Noble, Upper Cenozoic basalts with high $87 \mathrm{Sr} / 86 \mathrm{Sr}$ and $\mathrm{Sr} / \mathrm{Rb}$ ratios, southern Great Basin, western United States, Geol. Soc. Am. Bull., 82, 3503-3510, 1971.

Hoffine, S.R., Geochemistry of the volcanic rocks of the Saline Range, California: Implications for mantle composition and involvement in extension beneath the Basin and Range, M.S. thesis, 98 pp., Univ. of Kansas, Lawrence, 1993.

Hofmann, A.W., and W.M. White, Ba, Rb and $\mathrm{Cs}$ in the Earth's mantle, Z Naturforsch., 38, 256-266, 1983.

Joesten, R., Mineralogical and chemical evolution of contaminated igneous rocks at a gabbro-limestone contact, Christmas Mountains, Big Bend region, Texas, Geol. Soc. Am. Bull., 88, 1515 $1528,1977$.

Kargel, J.S., The geochemistry of basalts and mantle inclusions from the Lunar Crater Volcanic Field, Nevada: Petrogenetic and geodynamic implications, M.S. thesis, 393 pp., Ohio State Univ., Columbus, 1987.

Kay, R.W., S.S. Sun, and C.N. Lee-Hu, $\mathrm{Pb}$ and $\mathrm{Sr}$ isotopes in volcanic rocks from the Aleutian Islands and Pribilof Islands, Alaska, Geochim. Cosmochim. Acta, 42, 263-273, 1978.

Klein, E.M., and C.H. Langmuir, Global correlations of ocean ridge basalt chemistry with axial depth and crustal thickness, $J$. Geophys. Res., 92, 8089-8115, 1987.

Langenheim, R.L., and E.R. Larson, Correlation of Great Basin stratigraphic units, Nev. Bur. Mines Geol. Bull., 36, 351 pp., 1972.

Leeman, W.P., The isotopic composition of strontium in lateCenozoic basalts from the Basin-Range province, western United States, Geochim. Cosmochim. Acta, 34, 857-872, 1970.

Leeman, W.P., Tectonic and magmatic significance of strontium isotopic variations in Cenozoic volcanic rocks from the western United States, Geol. Soc. Am. Bull., 93, 487-503, 1982.

Le Maitre, R.W., A Classification of Igneous Rocks and Glossary of Terms, 193 pp., Blackwell Sci., Cambridge, Mass., 1989.
Livaccari, R.F., and F.V. Perry, Isotopic evidence for preservation of Cordilleran lithospheric mantle during the Sevier-Laramide orogeny, westem United States, Geology, 21, 719-722, 1993.

Luedke, R.G., and R.L. Smith, Map Showing Distribution, Composition, and Age of Late Cenozoic Volcanic Centers in California and Nevada, scale $1: 1,000,000$, U.S. Geol. Surv. Misc. Invest. Map, IIO9IC, 1981.

Lugmair, G.W., and R.W. Carlson, The Sm-Nd history of KREEP, Proc. Lunar Planet. Sci. Conf., 9th, 689-704, 1978.

Luhr, J.F., J.G. Pier, J.J. Aranda-Gomez, and F.A. Podoseck, Crustal contamination in early Basin-and-Range hawaiites of the Los Encinos Volcanic Field, central Mexico, Contrib. Mineral. Petrol., 118, 321$339,1995$.

Lum, C.L., W.P. Leeman, K.A. Foland, J.A. Kargel, and J.G. Fitton, Isotopic variations in continental basaltic lavas as indicators of mantle heterogeneity: Examples from the western U.S. Cordillera, $J$. Geophys. Res., 94, 7871-7884, 1989.

MacDonald, G.A., and T. Katsura, Chemical composition of Hawaiian lavas, J. Petrol., 5, 82-133, 1964.

Martin, M.W., and T.R. Naumann, Tertiary Geology of the Reveille Range Quadrangle, Northern Reveille Range, Nye County, Nevada, Map 104, scale 1:24,000, Nev. Bur. of Mines and Geol. Reno, 1995.

Masuda, A., N. Nakamura, and T. Tanaka, Fine structures of mutually normalized rare-earth patterns of chondrites, Geochim. Cosmochim. Acta, 37, 239-248, 1973.

Menzies, M.A., W.P. Leeman, and C.J. Hawkesworth, Isotope geochemistry of Cenozoic volcanic rocks reveals mantle heterogeneity below western USA, Nature, 303, 205-209, 1983.

Naumann, T.R., E.I. Smith, and M. Shafiqullah, Post-6 Ma intermediate (trachytic) volcanism in the Reveille Range, central Great Basin, Nevada, Geol. Soc. Am. Abstr. Programs, 22, 72, 1990.

Naumann, T.R., E.I. Smith, M. Shafiqullah, and P.E. Damon, New K-Ar ages for Pliocene mafic to intermediate volcanic rocks in the Reveille Range, Nevada, Isochron West, 57, 12-16, 1991.

O'Hara, M.J., The bearing of phase equilibria studies in synthetic and natural systems on the origin and evolution of basic and ultrabasic rocks, Earth Sci. Rev., 4, 69-133, 1968.

Ormerod, D.S., Late-to post-subduction magmatic transitions in the western Great Basin, USA, Ph.D. thesis, Open Univ. 313 pp., Milton Keynes, England, 1988.

Ormerod, D.S., C.J. Hawkesworth, N.W. Rogers, W.P. Leeman, and $M$. Menzies, Tectonic and magmatic transitions in the Western Great Basin, USA, Nature. 333, 349-353, 1988.

Rogers, N.W., C.J. Hawkesworth, and D.S. Ormerod, Late Cenozoic basaltic magmatism in the western Great Basin, Califomia and Nevada, J. Geophys. Res., 100, 10,287-10,301, 1995.

Scott, D.H., and N.J. Trask, Geology of the Lunar Crater Volcanic Field, Nye County, Nevada, U.S. Geol. Surv. Prof. Pap., 599-I, 122 pp., 1971.

Shaw, H.F., Sm-Nd in marine carbonates and phosphates: Implications for Nd isotopes in seawater and crustal ages, Geochim. Cosmochim. Acta, 49, 503-518, 1985.

Sun, S.S., and W.F. McDonough, Chemical and isotopic systematics of oceanic basalts: implications for mantle composition and processes, in Magmatism in the Ocean Basins, edited by A. D. Saunders and M. J. Norry, Geol. Soc. Spec. Publ., 42, 313-346, 1989.

Takahashi, E., and I. Kushiro, Melting of a dry peridotite at high pressures and basalt magma genesis, Am. Mineral., 68, 859-879, 1983.

Vaniman, D.T., B.M. Crowe, and E.S. Gladney, Petrology and geochemistry of Hawaiite lavas from Crater Flat, Nevada, Contrib. Mineral. Petrol., 80, 341-357, 1982.

Veizer, J., Chemical diagenesis of carbonates: theory and application of trace element technique, in Stable Isotopes in Sedimentary Geology, edited by M. A. Arthur SEPM Short Course, 10, 1983.

Walker, J.D., and D.S. Coleman, Geochemical constraints on mode of extension in the Death Valley region, Geology, 19, 971-974, 1991.

Wasserburg, G.J., S.B. Jacobsen, D.J. DePaolo, M.T. McCulloch, a n d T. Wen, Precise determination of $\mathrm{Sm} / \mathrm{Nd}$ ratios, $\mathrm{Sm}$ and $\mathrm{Nd}$ isotopic abundances in standard solutions, Geochim. Cosmochim. Acta, 45, 2311-2323, 1981.

Watson, E.B., Basalt contamination by continental crust: Some experiments and models, Contrib. Mineral. Petrol., 80, 73-87, 1982. 
Watson, E.B., and S.R. Jurewicz, Behavior of alkalies during diffusive interaction of granitic xenoliths with basaltic magma, J. Geol., 92, 121-131, 1983.

Wilkinson, J.F.G., The mineralogy and petrography of alkali basaltic rocks, in The Alkaline Rocks, edited by H. Sorensen, pp. 6795, John Wiley, New York, 1974.

Wyllie, P.J., Limestone assimilation, in The Alkaline Rocks, edited by $\mathrm{H}$. Sorensen, pp. 459-474, John Wiley, New York, 1974.

Zindler, A., and S. Hart, Chemical Geodynamics, Annu. Rev. Earth Planet. Sci., 14, 493-570, 1986.

T. K. Bradshaw, House of Lords Committee Offices, London SW1A OPW, England.
T. R. Naumann, Department of Geology, University of Idaho, P. O. Box 3952, Moscow, ID 83843-1920.

E. I. Smith, Center of Volcanic and Tectonic Studies, Department of Geosciences, University of Nevada, Las Vegas, NV 89154-4010.

J. D. Walker, Isotope Geochemistry Laboratory, Department of Geology, University of Kansas, 120 Lindley Hall, Lawrence, KS 66045-2124.

G. M. Yogodzinski, Department of Geology, Dickinson College, Carlisle, PA 17013-2896. (e-mail: yogodzin@dickinson.edu)

(Received July 17, 1995; revised February 15, 1996; accepted March 12, 1996.) 